\title{
Aging triggers an upregulation of a multitude of cytokines in the male and especially the female rodent hippocampus but more discrete changes in other brain regions
}

Latarsha Porcher ${ }^{1}$, Sophie Bruckmeier ${ }^{2}$, Steven D. Burbano ${ }^{1}$, Julie E. Finnell ${ }^{1}$, Nicole Gorny ${ }^{2}$, Jennifer Klett ${ }^{1}$, Susan K. Wood ${ }^{1}$ and Michy P. Kelly ${ }^{1,2,3^{*}}$ (i)

\begin{abstract}
Background: Despite widespread acceptance that neuroinflammation contributes to age-related cognitive decline, studies comparing protein expression of cytokines in the young versus old brains are surprisingly limited in terms of the number of cytokines and brain regions studied. Complicating matters, discrepancies abound-particularly for interleukin 6 (IL-6) - possibly due to differences in sex, species/strain, and/or the brain regions studied.

Methods: As such, we clarified how cytokine expression changes with age by using a Bioplex and Western blot to measure multiple cytokines across several brain regions of both sexes, using 2 mouse strains bred in-house as well as rats obtained from NIA. Parametric and nonparametric statistical tests were used as appropriate.

Results: In the ventral hippocampus of C57BL/6J mice, we found age-related increases in IL-1a, IL-1 $\beta$, IL-2, IL-3, IL-4, IL-6, IL-9, IL-10, IL-12p40, IL-12p70, IL-13, IL-17, eotaxin, G-CSF, interfeuron 8, KC, MIP-1a, MIP-1 b, rantes, and TNFa that are generally more pronounced in females, but no age-related change in IL-5, MCP-1, or GM-CSF. We also find aging is uniquely associated with the emergence of a module (a.k.a. network) of 11 strongly intercorrelated cytokines, as well as an age-related shift from glycosylated to unglycosylated isoforms of IL-10 and IL-1 $1 \beta$ in the ventral hippocampus. Interestingly, age-related increases in extra-hippocampal cytokine expression are more discreet, with the prefrontal cortex, striatum, and cerebellum of male and female C57BL/6J mice demonstrating robust age-related increase in IL-6 expression but not IL-1 $\beta$. Importantly, we found this widespread age-related increase in IL-6 also occurs in BALB/CJ mice and Brown Norway rats, demonstrating conservation across species and rearing environments.
\end{abstract}

\footnotetext{
*Correspondence: Michy.Kelly@som.umaryland.edu

'Pharmacology, Physiology \& Neuroscience, University of South Carolina School of Medicine, 6439 Garners Ferry Rd, Columbia, SC 29209, USA

${ }^{2}$ Department of Anatomy \& Neurobiology, University of Maryland School of Medicine, 20 Penn St, HSFII Rm 216, Baltimore, MD 21201, USA

Full list of author information is available at the end of the article
}

C C The Author(s). 2021 Open Access This article is licensed under a Creative Commons Attribution 4.0 International License, which permits use, sharing, adaptation, distribution and reproduction in any medium or format, as long as you give appropriate credit to the original author(s) and the source, provide a link to the Creative Commons licence, and indicate if changes were made. The images or other third party material in this article are included in the article's Creative Commons licence, unless indicated otherwise in a credit line to the material. If material is not included in the article's Creative Commons licence and your intended use is not permitted by statutory regulation or exceeds the permitted use, you will need to obtain permission directly from the copyright holder. To view a copy of this licence, visit http://creativecommons.org/licenses/by/4.0/ The Creative Commons Public Domain Dedication waiver (http://creativecommons.org/publicdomain/zero/1.0/) applies to the data made available in this article, unless otherwise stated in a credit line to the data. 
Conclusions: Thus, age-related increases in cytokines are more pronounced in the hippocampus compared to other brain regions and can be more pronounced in females versus males depending on the brain region, genetic background, and cytokine examined.

Keywords: Aged, Aging, Alzheimer's disease, Cytokine, Chemokine, Inflammatory, Inflammation, Hippocampus, Prefrontal cortex, Sex differences

\section{Background}

As humans age, cognitive decline can negatively affect everyday life even in relatively healthy individuals $[1,2]$. This cognitive decline is associated with atrophy and reduced plasticity in brain regions such as the hippocampus, cortex, striatum, and, eventually, the cerebellum (c.f [3-5].). In the hippocampus, for example, aging is associated with decreased neurogenesis (e.g., [6]), as well as decreased neuronal size, complexity, and connectivity [1]. The molecular mechanisms underlying this agerelated deterioration are not yet fully understood, but increased neuroinflammation is thought to play a role.

Many types of neuroinflammatory and neuroimmune pathways have been implicated in brain aging, including signals related to the Complement Cascade, Toll-like receptor signaling, antigen presentation, and IF $\mathrm{b} /$ $\mathrm{NF} b$ signaling as well as macrophage and microglia activation (e.g., $[7,8]$ ). Microglia are the brain's innate immune cell. Microglia normally reside in a quiescent state until a foreign antigen activates them, at which time they produce pro-inflammatory cytokines (including interleukins, tumor necrosis factors, interferons, and chemokines). Once the threat is resolved, microglia then produce anti-inflammatory cytokines that initiate the return to homeostasis [9]. Within the aging brain, an increase in macrophage infiltration, microglia priming, and/or microglia activation has been observed [9-13], along with a failure to return to homeostasis $[9,11,14$, 15]. Although the early stages of an immune response can be neuroprotective, chronic activation can be detrimental $[2,13,16,17]$. The chronic activation of microglia that is observed in the aging brain, particularly that within the hippocampus, is thought to cause persistent neuroinflammation that detrimentally affects cognitive function $[6,13,15,16,18-20]$.

Despite widespread acceptance that persistent neuroinflammation contributes to age-related cognitive decline [13], studies comparing protein expression of cytokines in young versus old brains are surprisingly limited in terms of the number of cytokines and brain regions studied and the fact that most studies only examined effects in either males or females. Studies suggest that aging is associated with increased tumor necrosis factor (TNF) protein expression in the hippocampus and prefrontal cortex $[21,22]$ but not the amygdala [22]. Although many studies have reported age- related increases in basal interleukin $1 \beta$ (IL-1 $\beta$ ) protein levels in the hippocampus of multiple mouse strains and Wistar rats [23-29], others find no such age-related increases in basal IL-1 $\beta$ protein expression in the hippocampus of F344xBN F1 rats specifically [22, 30-32]. That said, these same reports do find F344xBN F1 rats exhibit age-related exacerbation of IL- $1 \beta$ induction following a challenge [22, 30-32]. Outside of the hippocampus, reports are more limited with studies in SAMR1 mice reporting age-related increases in baseline IL-1 $\beta$ protein expression in the cortex, hypothalamus, and brain stem [29], but studies in C57BL/6J mice and F344xBN F1 rats reporting no such age-related increases in baseline IL-1 $\beta$ protein expression in the cortex, hypothalamus, or amygdala [22, 23, 30,31]. Findings around IL-6 are even more discrepant. Although 2 studies reported age-related increases in IL-6 protein expression in the hippocampus (BALB/cJ mice, [33]; strain not specified, [21]), 2 other studies did not (C57BL/6J males, [23]; F344xBN F1 Rats, [22]). Similarly, 3 studies reported age-related increases in IL-6 protein expression in the cortex (BALB/cJ mice, [33]; C57BL/6J females, [34]; strain not specified, [21]); however, a fourth did not (C57BL/6J males, [23]).

Discrepancies in the above finding may be related to environmental factors that differ between labs, the brain region examined, the species/strain used in the study, and/or the sex of the subjects employed. For example, diet, immune status (e.g., rearing in a pathogen-free facility), and other environmental factors have been shown to preferentially upregulate cytokine expression in aged vs. young adult brains [11, 12, 35-37]. Pathway analyses suggest that age-related changes in inflammation- and immune-related gene expression may be more pronounced in the hippocampus compared to other brain regions and more pronounced in females versus males $[7,8]$. Indeed, we noted that studies employing female subjects alone or in combination with male subjects routinely report higher basal IL-6 mRNA or protein expression in old vs. young brains [8, 34, 38, 39]; whereas, only a subset of studies employing male subjects alone report this age-related increase in basal expression (increased mRNA: [36]; increased protein: [21, 33, 40-42]; no change mRNA: $[11,12,35,43]$; no change protein: [22, $23,37])$. As such, we sought to clarify how proinflammatory (IL-1 $\alpha$, IL-1 $\beta$, IL-2, IL-3, IL-5 IL-6-see 
discussion, IL-9, IL-12p40, IL-12p70, IL-17, eotaxin, interfeuron $\delta, \mathrm{KC}, \mathrm{MIP}-1 \mathrm{a}, \mathrm{MIP}-1 \mathrm{~b}$, rantes, $\mathrm{TNF} \alpha$, MCP-1, or GM-CSF) and anti-inflammatory cytokine expression (IL-4, IL-10, IL-13, G-CSF) may change with age by studying multiple cytokines across multiple brain regions of both male and female subjects, using 2 strains of mice bred in-house as well as rats obtained from the NIA aging colony. Here, we find that in the ventral hippocampus, both pro- and anti-inflammatory cytokines increased with the age in males and even more so in females. Interestingly, while IL-6 was dramatically upregulated with age in all brain regions and subjects examined, IL1- $\beta$ was only elevated in the ventral and dorsal hippocampus.

\section{Methods}

\section{Subjects}

C57BL/6J and BALB/CJ mice were originally obtained from Jax and then bred onsite at the University of South Carolina School of Medicine. Young mice ranged from 2 to 5 months old, middle-aged mice ranged from 9 to 12 months old, and old mice ranged from 18 to 24 months old. Litter effects are unlikely to account for effects described herein as mice were derived from multiple litters and were housed across multiple cages. Further, several sample sets analyzed by Western blot were obtained from multiple cohorts of mice born and raised at different times in our facility, with some cohorts including young, middle-aged and old mice, and other cohorts including only young and old mice. Young ( 4 months old) and old (19 months old) Brown Norway Rats were obtained directly from the NIA colony and allowed to acclimate to the animal facility at the University of South Carolina School of Medicine for 1 week prior to tissue harvest. Animals are housed on a 12:12 light:dark cycle and allowed ad lib access to food and water. Experiments were carried out in accordance with the National Institutes of Health Guide for the Care and Use of Laboratory Animals (Pub 85-23, revised 1996) and were fully approved by the Institutional Animal Care and Use Committee of the University of South Carolina and the University of Maryland, Baltimore. See Table 1 for specific n's in each experiment. Note that males and females were used throughout all experiments but not necessarily in sufficient number to power an analysis of age $x$ sex. Mice are generally healthy at the time of tissue harvest. We do not conduct gross pathology; however, mice are routinely assessed by husbandry, veterinary, and laboratory staff and mice with palpable tumors, lethargy, altered gait, signs of malnutrition, or dehydration are removed from the study and euthanized. If mice were to demonstrate evidence of a striking anatomical abnormality of the brain upon dissection (e.g., a pituitary tumor), they would also not be included since it is our intent is to study the effects of healthy aging. Note that a previous study found $\sim 35 \%$ of C57BL6 female mice raised in a pathogen-free facility exhibited pituitary tumors [44]; however, we came upon only a handful of these readily identifiable tumors (or tumors of any sort) in the brains of our $\mathrm{C} 57 \mathrm{BL} / 6 \mathrm{~J}$ mice raised in a conventional animal facility.

\section{Tissue collection}

Mice were euthanized during the light cycle via cervical dislocation, whilst rats were euthanized during the light cycle by $\mathrm{CO}_{2}$ inhalation. Mouse brains were harvested fresh, dissected on wet ice, and stored at $-80^{\circ} \mathrm{C}$ for further processing. Rat brains were harvested fresh, hemisected over wet ice, frozen in isopentane over dry ice, and half brains were then stored at $-80^{\circ} \mathrm{C}$. Later, the cerebellum and prefrontal cortex were dissected from frozen rat half brains on dry ice. All brain regions examined in the BALB/cJ mice were dissected from the same group of animals.

\section{Bioplex}

A Bio-Plex Pro Mouse Cytokine 23-Plex (Bio-Rad, Hercules CA) was used to probe ventral hippocampal homogenates for cytokines. Methods for the tissue preparation were based on previously published work in rat brain homogenates $[45,46]$. Briefly, ventral hippocampal samples were homogenized in boiling lysis buffer (50$\mathrm{mM} \mathrm{NaF/1 \%} \mathrm{SDS} \mathrm{[47];),} \mathrm{and} \mathrm{then,} \mathrm{homogenates} \mathrm{were} \mathrm{di-}$ luted in sample diluent containing 1\% FBS. Standards were reconstituted in lysis buffer containing $1 \%$ FBS and diluted via serial dilution such that all analytes reached a minimum concentration of $0.2 \mathrm{pg} / \mathrm{mL}$. Bioplex data were collected over 3 runs using the same plate. In the first run, $1 / 2$ of the wells were used to test all samples at a concentration of $0.275 \mu \mathrm{g} / \mu \mathrm{L}$ based on our previous work with rat tissue $[45,46]$. Unfortunately, many targets were unable to be detected due to matrix effects or reached ceiling effects at that high of a concentration (See Table S1). In the 2nd run, we used approximately $1 / 4$ of the wells to retest $1 / 2$ of these samples at a concentration of $0.1 \mu \mathrm{g} / \mu \mathrm{L}$. We found $0.1 \mu \mathrm{g} / \mu \mathrm{L}$ allowed detection of all targets except IL-5. Therefore, in a 3rd run we used the remaining $1 / 4$ of the plate to retest the other $1 / 2$ of the samples at a concentration of $0.05 \mu \mathrm{g} / \mu \mathrm{L} .0 .05 \mu \mathrm{g} /$ $\mu \mathrm{L}$ enabled detection of all targets. The pattern of effects was consistent across the subsets of samples tested at $0.1 \mu \mathrm{g} / \mu \mathrm{L}$ and $0.05 \mu \mathrm{g} / \mu \mathrm{L}$. As such, data from each concentration were expressed as a fold change of the young mean and combined in analyses. Bead preparation, handling, and plate processing were conducted according to manufacturer protocol. Plates were washed using a Bio-Plex Pro II Wash Station (Bio-Rad, Hercules, CA) and read using a Luminex SD system (Bio-Rad, Hercules 
Table 1 Statistics and $n$ 's for experiments shown in Figs. 1, 2, 3, 4, and 5

\begin{tabular}{|c|c|c|c|c|c|c|c|c|c|c|}
\hline Figure & YM & YF & $\begin{array}{l}\text { MM } \\
n=\end{array}$ & MF & OM & OF & Normality & $\mathrm{EV}^{\mathrm{a}}$ & effect of age & Effect of sex \\
\hline $1 \mathrm{~A}$ & 4 & 3 & & & 4 & 3 & Pass & Fail & Rank sum: $T(7,7)=35.00$, FDR-P $=0.036$ & \\
\hline 1B & 4 & 3 & & & 4 & 3 & Pass & Fail & Rank sum: $T(7,7)=30.50$, FDR-P $=0.013$ & \\
\hline $1 C$ & 4 & 3 & & & 4 & 3 & Pass & Pass & Student's $t: t(12)=-3.472, F D R-P=0.019$ & \\
\hline $1 \mathrm{D}$ & 4 & 3 & & & 4 & 3 & Pass & Pass & Student's $t: t(12)=-2.375, F D R-P=0.044$ & \\
\hline $1 \mathrm{E}$ & 4 & 3 & & & 4 & 3 & Pass & Pass & Student's $t: t(12)=-3.128, F D R-P=0.023$ & \\
\hline $1 F$ & 2 & 1 & & & 2 & 1 & Pass & Pass & Student's $t: t(4)=-1.53, F D R-P=0.178$ & \\
\hline $1 \mathrm{G}$ & 4 & 3 & & & 4 & 3 & Pass & Fail & Rank sum: $T(7,7)=31.00$, FDR-P $=0.019$ & \\
\hline $1 \mathrm{H}$ & 4 & 3 & & & 4 & 3 & Pass & Pass & Student's $t: t(12)=-2.340, F D R-P=0.044$ & \\
\hline 11 & 4 & 3 & & & 4 & 3 & Fail & & Rank sum: $T(7,7)=32.00, F D R-P=0.023$ & \\
\hline $1 \mathrm{~J}$ & 4 & 3 & & & 4 & 3 & Fail & & Rank sum: $T(7,7)=32.00$, FDR-P $=0.023$ & \\
\hline $1 \mathrm{~K}$ & 4 & 3 & & & 4 & 3 & Pass & Pass & Student's $t: t(12)=-5.641, F D R-P=0.002$ & \\
\hline $1 \mathrm{~L}$ & 4 & 3 & & & 4 & 3 & Fail & & Rank sum: $T(7,7)=28.50$, FDR-P $=0.007$ & \\
\hline $1 \mathrm{M}$ & 4 & 3 & & & 4 & 3 & Pass & Fail & Rank sum: $T(7,7)=34.00, F D R-P=0.029$ & \\
\hline $1 \mathrm{~N}$ & 4 & 3 & & & 4 & 3 & Fail & & Rank sum: $T(7,7)=28.00$, FDR-P $=0.007$ & \\
\hline 10 & 4 & 3 & & & 4 & 3 & Fail & & Rank sum: $T(7,7)=33.50$, FDR-P $=0.025$ & \\
\hline $1 \mathrm{P}$ & 4 & 3 & & & 4 & 3 & Pass & Pass & Student's $t: t(12)=-1.052, F D R-P=0.314$ & \\
\hline $1 \mathrm{Q}$ & 4 & 3 & & & 4 & 3 & Pass & Pass & Student's $-t: t(12)=-2.386, F D R-P=0.044$ & \\
\hline $1 \mathrm{R}$ & 4 & 3 & & & 4 & 3 & Pass & Pass & Student's $t: t(12)=-2.996$, FDR-P $=0.025$ & \\
\hline 15 & 4 & 3 & & & 4 & 3 & Fail & & Rank sum: $T(7,7)=41.00$, FDR-P $=0.179$ & \\
\hline $1 \mathrm{~T}$ & 4 & 3 & & & 4 & 3 & Pass & Pass & Student's $t: t(12)=-2.554, F D R-P=0.036$ & \\
\hline $1 U$ & 4 & 3 & & & 4 & 3 & Fail & & Rank sum: $T(7,7)=33.00$, FDR-P $=0.025$ & \\
\hline $1 \mathrm{~V}$ & 4 & 3 & & & 4 & 3 & Pass & Pass & Student's $t: t(12)=-2.836, F D R-P=0.027$ & \\
\hline $1 \mathrm{~W}$ & 4 & 3 & & & 4 & 3 & Pass & Fail & Rank sum: $T(7,7)=34.50$, FDR-P $=0.026$ & \\
\hline 2A-left & 7 & 7 & 4 & 4 & 8 & 6 & Fail & & ANOVA on ranks: $H(2)=1.51, P=0.471$ & Rank sum: $T(6,8)=47.0, P=0.852$ \\
\hline 2A-right & 7 & 7 & 4 & 4 & 8 & 6 & Pass & Fail & ANOVA on ranks: $H(2)=8.505, P=0.014^{c}$ & Rank sum: $T(5,8)=41.0, P=0.435$ \\
\hline $2 B$ & 13 & 13 & 17 & 16 & 16 & 13 & Fail & & ANOVA on ranks: $H(2)=44.227, P<0.001^{c}$ & Rank sum: $T(13,16)=252.00, P=0.013$ \\
\hline 2C-left & 9 & 5 & & & 9 & 4 & Pass & Fail & Rank sum: $T(13,14)=226.00, P=0.035$ & Rank sum: $T(4,9)=31.0, P=0.70$ \\
\hline 2C-right & 9 & 5 & & & 9 & 4 & Pass & Fail & Rank sum: $T(13,14)=247.00, P=0.002$ & Rank sum: $T(4,9)=30.0, P=0.817$ \\
\hline $3 \mathrm{~A}$ & 9 & 8 & 12 & 11 & 17 & 14 & Fail & & ANOVA on Ranks: $H(2)=50.059, P<0.001^{c}$ & Rank sum: $T(14,17)=230.0, P=0.827$ \\
\hline 3B-left & 6 & 5 & & & 5 & 5 & Pass & Pass & 2-Way ANOVA: $F(1,17)=11.207, P=0.004$ & 2-Way ANOVA: $F(1,17)=0.01, P=0.928$ \\
\hline 3B-right & 6 & 5 & & & 5 & 5 & Pass & Pass & 2-Way ANOVA: $F(1,17)=11.443, P=0.004$ & 2-Way ANOVA: $F(1,17)=0.003, P=0.955$ \\
\hline $3 C$ & 15 & 12 & & & 9 & 14 & Fail & & Rank sum: $T(23,27)=289.0, P<0.001$ & Rank sum: $T(4,8)=23.0, P=0.683$ \\
\hline 3D-left & 2 & 3 & & & 2 & 3 & Pass & Pass & Student's $t: t(8)=0.43, P=0.677$ & \\
\hline 3D-right & 2 & 3 & & & 2 & 3 & Pass & Pass & Student's $t: t(8)=0.18, P=0.862$ & \\
\hline $3 \mathrm{E}$ & 16 & 13 & & & 10 & 10 & Pass & Pass & 2-Way ANOVA: $F(1,45)=74.93, P<0.001$ & 2-Way ANOVA: $F(1,16)=0.22, P=0.649$ \\
\hline 3F-left & 11 & 6 & & 11 & 7 & Fail & & & Rank sum: $T(17,18)=270.5, P=0.248$ & Rank sum: $T(7,11)=50.0, P=0.147$ \\
\hline 3F-right & 11 & 7 & & 11 & 7 & Pass & Fail & & Rank sum: $T(18,18)=328.0, P=0.887$ & Rank sum: $T(7,11)=46.0, P=0.07$ \\
\hline $3 G$ & 14 & 13 & 16 & 17 & 16 & 16 & Fail & & ANOVA on ranks: $H(2)=53.334, P<0.001^{c}$ & Rank sum: $T(15,16)=207.0, P=0.199$ \\
\hline $3 \mathrm{H}$ & 9 & 9 & 4 & 4 & 9 & 9 & Pass & Pass & 2-Way ANOVA: $F(2,38)=1.90, P=0.163$ & 2-Way ANOVA: $F(1,6)=0.37, P=0.564$ \\
\hline $4 \mathrm{~A}$ & 2 & 5 & & & 2 & 5 & Pass & Fail & Rank sum: $T(7,7)=30.0, P=0.002$ & \\
\hline $4 \mathrm{~B}$ & 2 & 5 & & & 2 & 5 & Fail & & Rank sum: $T(7,7)=28.0, P<0.001$ & \\
\hline $4 C$ & 2 & 5 & & & 2 & 5 & Fail & & Rank sum: $T(7,7)=29.0, P=0.001$ & \\
\hline $4 \mathrm{D}$ & 2 & 5 & & & 2 & 5 & Fail & & Rank sum: $T(7,7)=28.0, P<0.001$ & \\
\hline
\end{tabular}


Table 1 Statistics and $n$ 's for experiments shown in Figs. 1, 2, 3, 4, and 5 (Continued)

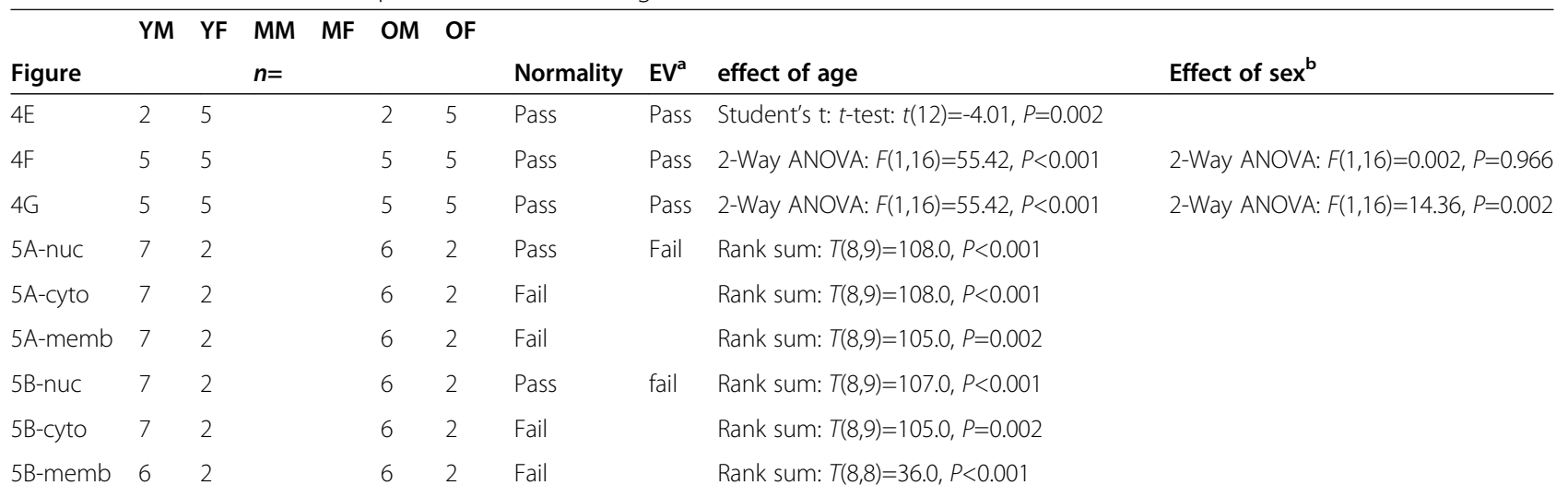

YM young males, $Y F$ young females, MM middle-aged males, MF middle-aged females, OM old males, OF old females, EV equal variance, FDR corrected for multiple comparisons using false detection rate

${ }^{a}$ Equal variance only tested when dataset passed normality

${ }^{b}$ Effect of sex only analyzed in experiments where $n>4$ /sex/age. Rank sum used when 2-way ANOVA for age $x$ sex failed normality or equal variance and reports

effect of sex within old mice. 2-way ANOVA used when normality and equal variance pass and reports main effect of sex across ages

"See the "Results" section for post hoc tests

CA) housed within the Instrument Resource Facility at the University of South Carolina School of Medicine.

\section{Western blots}

Samples for select C57BL/6J Westerns, BALB/cJ Westerns, and rat Westerns were homogenized using a sonic dismembrator (a.k.a. tissue sonicator), as previously described $[47,48]$, in boiling lysis buffer $(50 \mathrm{mM} \mathrm{NaF} / 1 \%$ SDS). The tissue for the remaining C57BL/6J Westerns was homogenized as previously described [47] in icecold lysis buffer (20 mM Tris- $\mathrm{HCl}$, pH 7.5; $2 \mathrm{mM} \mathrm{MgCl}$; Thermo Pierce Scientific phosphatase tablet \#A32959 and protease inhibitor 3 \# 0044 ) in preparation for subsequent biochemical fractionation of the samples. There were no differences in the pattern of Western results obtained with one or the other lysis buffer, and so data were combined. Total protein quantity was determined for all homogenized tissue using the DC Protein Assay kit (BioRad, Inc.; Hercules, CA), and western blots were carried out as previously outlined $[47,48]$. For all blots, $36.3 \mu \mathrm{g}$ of total protein or $22 \mu \mathrm{g}$ of fractionated protein was loaded onto $4-12 \%$ Bis-Tris gels (Life Technologies) for electrophoresis. Following transfer to nitrocellulose membranes (\#10600008, Amersham), all blots except those testing the biochemical fractionations were subjected to PonceauS (\#6266-79-5, Fisher Scientific) to stain the total protein in each sample. Following image capture, The PonceauS was washed off with ultrapure water and TBST and the membranes were cut according to the molecular weight of the target of interest (Figure S1). Superblock (\#37515, Thermofisher) was then used at room temperature to block non-specific binding sites on membranes, and membranes were subsequently probed overnight at $4^{\circ} \mathrm{C}$ with primary antibodies against IL-6 (early experiments with 1:200 of MAB406 from
R\&D Systems; later experiments with 1:2500 of ARX0962 from Life Technologies), IL-1 $\beta$ (ab106034 from Abcam, 1:5,000), IL-10 (ARG2419 from Arigo Biolaboratories, 1:500), and actin (A2066 from Sigma, 1: 10,000) in Pierce Superblock (P137517)/0.1\% Tween20 (Fisher BP337-500). The following day, blots were washed in TBST and incubated for $1 \mathrm{~h}$ at room temperature with a species-specific HRP-tagged secondary antibody (Jackson, 1:10,000). Blots probed with IL-6 and IL- $1 \beta$ were developed using WesternSure Premium Chemiluminescent Substrate (926-95000), whereas blots probed with actin were developed using Pierce SuperSignal West Pico CL Substrate (\#34078). Blots were then apposed to film, scanned in at $1200 \mathrm{dpi}$, and quantified by densitometry using Image $(\mathrm{NIH})$ by a group-blinded experimenter. Data from the biochemical fractions were normalized to actin as a loading control as these data were obtained several years prior to the lab implementing the use of PonceauS. All other Western data were normalized to PonceauS staining intensity as a loading control. Unadjusted images of the full blots and membranes from which cropped images were pulled are shown in Figures S1-S8.

\section{Data analysis}

Biochemical data were collected by an experimenter blind to treatment, and Sigmaplot 11.2 was used to analyze data. As described above, Bioplex data were obtained from 2 separate runs, each using a different concentration of tissue. Therefore, Bioplex data from each run were normalized to the young group from that run. Similarly, Western data for a given experiment span multiple gels and so are normalized to the Young group on each gel in order to mitigate any non-specific differences between blots related to transfer efficiencies, film 
exposures, etc. (as in $[47,48]$ ). For Westerns, each brain region and fraction were run on separate sets of blots and so resultant data are analyzed with individual statistical tests per region or fraction. Both males and females were included in each group, but not always in sufficient number to analyze for an effect sex. For experiments with fewer than $n=4 /$ sex/group, data were analyzed for age only. For experiments that included at least $n=4 / \operatorname{sex} /$ group, data were analyzed for both age and sex. Parametric statistics were used (i.e., 2-factor ANOVA or Student $t$ test) when datasets passed normality (Shapiro-Wilk test) and equal variance (Levene's test). In cases where 2-factor ANOVAs failed assumptions of normality and/or equal variance, statistical tests for each factor were conducted separately. When statistical tests failed normality and/or equal variance, a nonparametric Whitney rank sum test or Kruskal-Wallis ANOVA on ranks was used. Correlations were conducted using Spearman rank order. Given all Bioplex data were derived from the simultaneous measurement of multiple endpoints, a false-rate discovery (FDR) correction was applied to all $P$ values to mitigate the risk of type I error associated with multiple comparisons. Outliers $>2$ standard deviations from the mean were removed from analyses consistent with our previous publications (e.g., [47, 49]; outliers/total data points: Fig. 2A, 3/72; Fig. 3F, 1/72; Fig. 3G, 3/92).

\section{Results}

Bioplex reveals pervasive upregulation of cytokines with age in the ventral hippocampus

To determine if the ventral hippocampus exhibits a widespread upregulation of cytokines with age, we used a Bioplex to simultaneously measure 23 such endpoints in young versus old C57BL/6J mice. Relative to young mice, old mice expressed significantly higher levels of IL- $1 \alpha$, IL1 $\beta$, IL-2, IL-3, IL-4, IL-6, IL-9, IL-10, IL-12p40, IL-12p70, IL-13, IL-17, eotaxin, granulocyte colony-stimulating factor, interferon $\delta, \mathrm{KC}$, macrophage inflammatory protein 1a (MIP-1a), MIP-1b, rantes, and TNF $\alpha$ (Fig. 1; Table 1). The age-related increases in the above noted pro-inflammatory and anti-inflammatory cytokines occurred in equal proportion, with only the ratio of IL-1 $/$ IL-13 differing significantly between old and young mice (Table 2). Effects noted in females tended to be stronger than those noted in males (Figure S9); however, the study was not powered for an analysis of sex effects (see Western data below). The agerelated increases in IL-5 and monocyte chemoattractant protein 1 failed to reach the level of statistical significance and granulocyte-macrophage colony-stimulating factor showed no difference in expression between young and old mice. In addition to expression changes, aging was also associated with the emergence of novel correlations in expression that were not observed in young mice. Whereas young mice only showed 9 significant correlations (no more than 3 for a given cytokine), old mice showed a total of 80 significant correlations (Table S2; Figure 1X). Interestingly, these significant correlations in old mice were not randomly distributed. Rather, 65/80 significant correlations fell within a module (i.e., a cluster of cytokines whose signals strongly correlate with each other [50]) of 11 cytokines (IL$1 \alpha$, IL-1 $\beta$, IL-3, IL-6, KL12p40, IL-13, IL17, KC, MCP-1, MIP-1b, and Rantes; Table S3). The degree of correlation was not related to the effect size of the age-related increases, with cytokines showing no, small or large changes represented amongst both the highly and rarely correlated cytokines. The degree of correlation was also not related to the designation of anti- vs pro-inflammatory, with members of each family amongst the highly versus rarely correlated cytokines. Among the highly correlated cytokines, IL-1 $\beta$, IL-3, IL-6, KL12p40, IL-13, IL17, KC, and MCP-1 formed a particularly tightly coupled core module, with each correlated to the other. Taken together, these data suggest the ventral hippocampus exhibits a dramatic change in the regulation of cytokines with age.

\section{Western blots confirm age-related increases in ventral hippocampal cytokines}

To confirm results obtained from the Bioplex and further investigate potential sex effects, IL-10, IL-6, and IL- $1 \beta$ expression in the ventral hippocampus were assessed using Western blots. In the ventral hippocampus of C57BL/6 mice, expression of presumed unglycosylated IL-10 (i.e., lower band on Western blot) appears to increase with age across males and females, whereas expression of presumed glycosylated IL-10 (i.e., upper band on Western blot) appears to remain stable (Fig. 2A; see Table 1 for statistics; post hoc: young vs. middle age $P=0.035$, young vs. old $P=0.046$ ). As such, the ratio of glycosylated/unglycosylated IL-10 decreased with age (Figure S10A). In contrast, both presumed unglycosylated and glycosylated forms of IL- $1 \beta$ increased in expression with age in both males and females (Fig. 2C; see Table 1 for statistics). Even though both isoforms of IL-1 $\beta$ increased with age, the ratio of glycosylated/unglycosylated IL-1 $\beta$ still decreased with age as was seen with IL-10 (Figure S10B). IL-6 expression also increased across the lifespan of male and female C57BL/6J mice (Fig. 2B; see Table 1 for statistics; post hoc: young vs. middle-aged $P=0.049$, young vs. old $P<0.001$; middle-aged vs old $P<0.001$ ), but females showed a much larger age-related increase than males. Together, these data support a widespread upregulation of cytokines in the ventral hippocampus with age.

\section{Western blots show age-related increases in cytokines are more discreet in extrahippocampal brain regions}

To determine the extent to which cytokines are upregulated with age in the brain, Western blots were used to analyze IL- 6 and IL- $1 \beta$ in the dorsal hippocampus, prefrontal cortex (PFC), striatum, and cerebellum of 


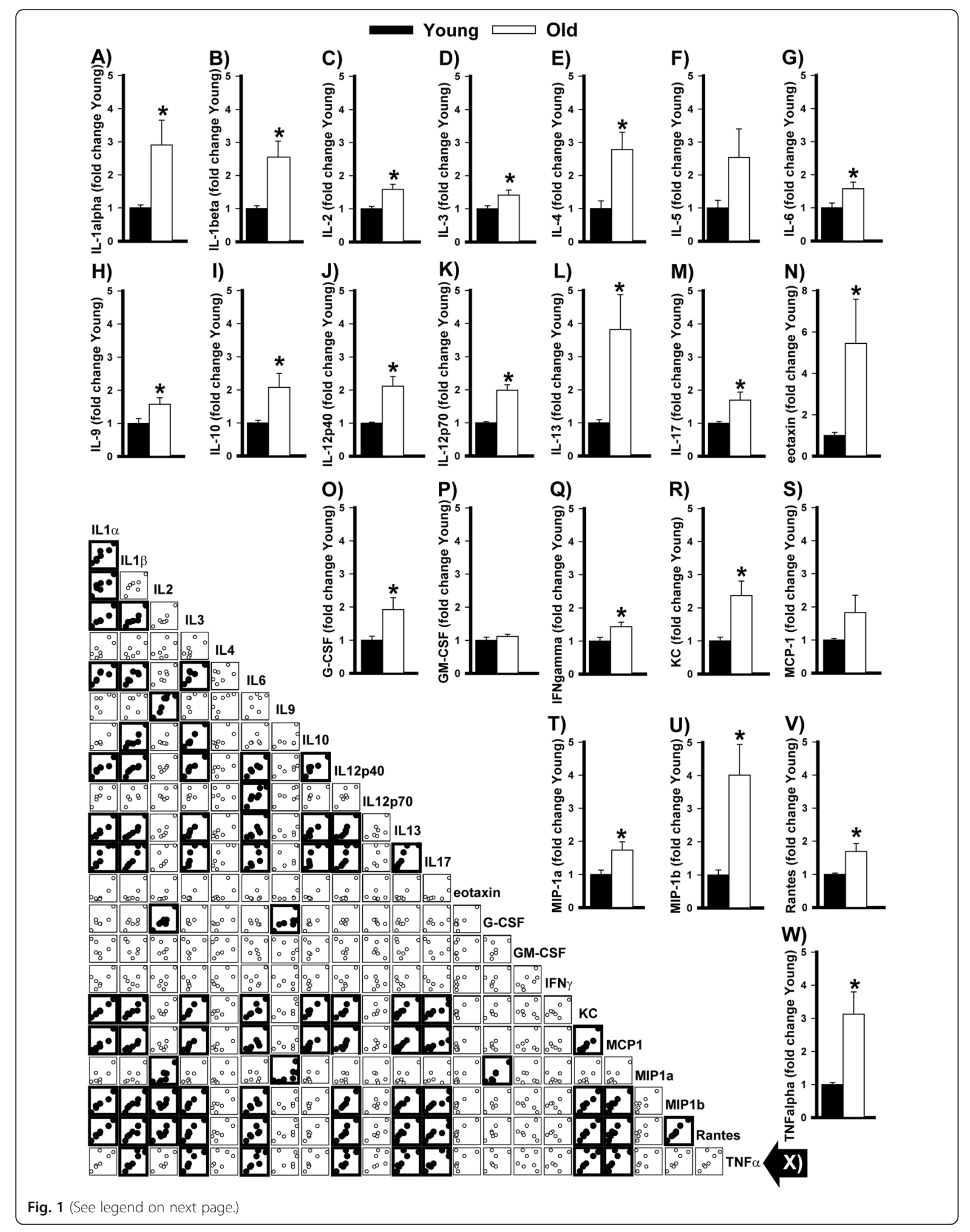


(See figure on previous page.)

Fig. 1 Bioplex analyses show widespread upregulation of cytokines in old versus young C57BL/6J ventral hippocampus. Cytokine expression was measured in the ventral hippocampus of young versus old C57BL/6J. Relative to young mice, old mice expressed significantly higher levels of $\mathbf{A}$

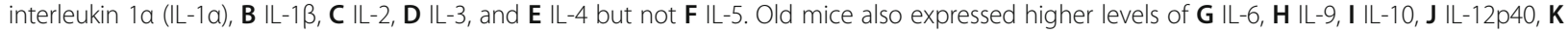
IL-12p70, L IL-13, $\mathbf{M}$ IL-17, N eotaxin, and $\mathbf{O}$ granulocyte colony-stimulating factor (G-CSF), but not $\mathbf{P}$ granulocyte-macrophage colony-stimulating factor (GM-CSF). Q Interfeuron gamma (IFNY) also exhibited an age-related increase, as did $\mathbf{R}$ KC but not $\mathbf{S}$ monocyte chemoattractant protein 1 (MCP1). Finally, $\mathbf{T}$ macrophage inflammatory protein 1a (MIP-1a), $\mathbf{U}$ MIP-1 b, $\mathbf{V}$ rantes, and $\mathbf{W}$ tumor necrosis factor (TNFa) all demonstrated agerelated increases in expression. $\mathbf{X}$ Correlational analyses (bold $=$ FDR-P $<0.05)$ of data from old mice reveals that a subset of these cytokines become uniquely coupled with each other in the aged ventral hippocampus (i.e., IL-1a, IL-1ß, IL-3, IL-6, KL12p40, IL-13, IL17, KC, MCP-1, MIP-1b and Rantes; see Table S2 for $r$ and $P$ values for both young and old mice). Data expressed as mean \pm SEM. *vs. young, FDR-P=0.044-0.002. FDR-false discovery rate

Table 2 Ratios of pro/anti-inflammatory cytokines suggest both types of cytokines are largely upregulated in the ventral hippocampus of old versus young C57BL/6J mice to the same extent

\begin{tabular}{|c|c|c|c|c|c|c|c|}
\hline Ratio $^{a}$ & Young mean & Young SEM & Old mean & Old SEM & Student's $T$ test or rank sum & Raw $P$ value & FDR-P value \\
\hline $\mathrm{IL}-1 \mathrm{a} / \mathrm{IL}-10$ & 1.00 & 0.05 & 1.30 & 0.18 & Failed EV: $T(7,7)=39.00$ & 0.0973 & 0.37537 \\
\hline $\mid \mathrm{L}-1 \beta / \mathrm{IL}-10$ & 1.01 & 0.06 & 1.25 & 0.13 & $t(12)=-1.705318$ & 0.1139 & 0.38428 \\
\hline IL-2/IL-10 & 1.04 & 0.12 & 0.85 & 0.08 & $t(12)=1.317512$ & 0.2123 & 0.4776 \\
\hline IL-6/IL-10 & 1.03 & 0.08 & 1.09 & 0.12 & $t(12)=-0.369068$ & 0.7185 & 0.84346 \\
\hline IL-12p40/IL-10 & 1.04 & 0.09 & 1.09 & 0.09 & $t(12)=-0.391351$ & 0.7024 & 0.90308 \\
\hline IL-12p70/IL-10 & 1.05 & 0.12 & 1.09 & 0.14 & $t(12)=-0.232436$ & 0.8201 & 0.88573 \\
\hline G-CSF/IL-10 & 1.01 & 0.10 & 0.95 & 0.08 & $t(12)=0.469474$ & 0.6471 & 0.87365 \\
\hline IFNץ/IL-10 & 1.03 & 0.12 & 0.80 & 0.14 & $t(12)=1.204295$ & 0.2517 & 0.48541 \\
\hline MIP-1a/IL-10 & 1.13 & 0.29 & 0.91 & 0.10 & Failed normality: $T(7,7)=55.00$ & 0.8048 & 0.90538 \\
\hline TNFa/IL-10 & 1.02 & 0.05 & 1.53 & 0.28 & Failed normality: $T(7,7)=37.00$ & 0.0530 & 0.28636 \\
\hline $\mid \mathrm{L}-1 \mathrm{a} / \mathrm{IL}-4$ & 1.00 & 0.18 & 1.06 & 0.20 & $t(12)=-0.21$ & 0.8382 & 0.87044 \\
\hline IL-1 $\beta / I L-4$ & 1.00 & 0.19 & 0.98 & 0.15 & $t(12)=0.10$ & 0.9183 & 0.9183 \\
\hline IL-2/IL-4 & 0.99 & 0.20 & 0.66 & 0.11 & $t(12)=1.46$ & 0.1727 & 0.4239 \\
\hline IL-6/IL-4 & 1.02 & 0.17 & 0.87 & 0.16 & $t(12)=0.64$ & 0.5300 & 0.795 \\
\hline IL-12p40/IL-4 & 0.99 & 0.15 & 0.86 & 0.13 & $t(12)=0.64$ & 0.5400 & 0.76737 \\
\hline IL-12p70/IL-4 & 0.96 & 0.15 & 0.87 & 0.17 & $t(12)=0.38$ & 0.7100 & 0.87136 \\
\hline G-CSF/IL-4 & 1.07 & 0.22 & 0.76 & 0.13 & $t(12)=1.30$ & 0.2200 & 0.45692 \\
\hline IFNg/IL-4 & 1.02 & 0.26 & 0.60 & 0.10 & $t(12)=1.59$ & 0.1400 & 0.42 \\
\hline MIP-1a/IL-4 & 0.92 & 0.09 & 0.68 & 0.08 & $t(12)=2.06$ & 0.0636 & 0.2862 \\
\hline TNFa/IL-4 & 0.99 & 0.16 & 1.22 & 0.26 & $t(12)=-0.72$ & 0.4844 & 0.76934 \\
\hline IL-1ß/IL6 & 1.00 & 0.06 & 1.19 & 0.10 & Failed normality: $T(7,7)=16.0$ & 0.3200 & 0.576 \\
\hline GM-CSF/IL-6 & 1.01 & 0.10 & 0.62 & 0.12 & $t(12)=2.563987$ & 0.0248 & 0.33506 \\
\hline IFNy/IL-6 & 1.01 & 0.11 & 0.76 & 0.13 & $t(12)=1.451187$ & 0.1724 & 0.46538 \\
\hline IL-1a/IL-13 & 1.01 & 0.06 & 0.76 & 0.09 & $t(12)=2.445990$ & 0.0308 & 0.27736 \\
\hline$|L-1 \beta /| L-13$ & 1.02 & 0.05 & 0.74 & 0.05 & $t(12)=3.973891$ & 0.0018 & 0.04987 \\
\hline MIP-1a/IL-13 & 1.15 & 0.33 & 0.58 & 0.11 & Failed normality: $T(7,7)=68.0$ & 0.0530 & 0.35775 \\
\hline TNFa/IL-13 & 1.05 & 0.11 & 0.89 & 0.12 & $t(12)=1.02$ & 0.3286 & 0.55451 \\
\hline
\end{tabular}

EV equal variance

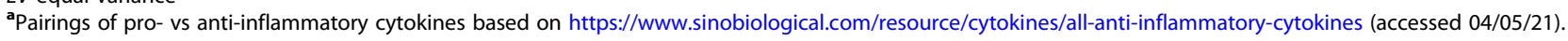
Note that 1 young subject expressed no IL-4; therefore, data from this subject could not be expressed as a ratio. Thus, $n=7 / a g e$ for all except for IL-4 ratios where $n=6$ for young 


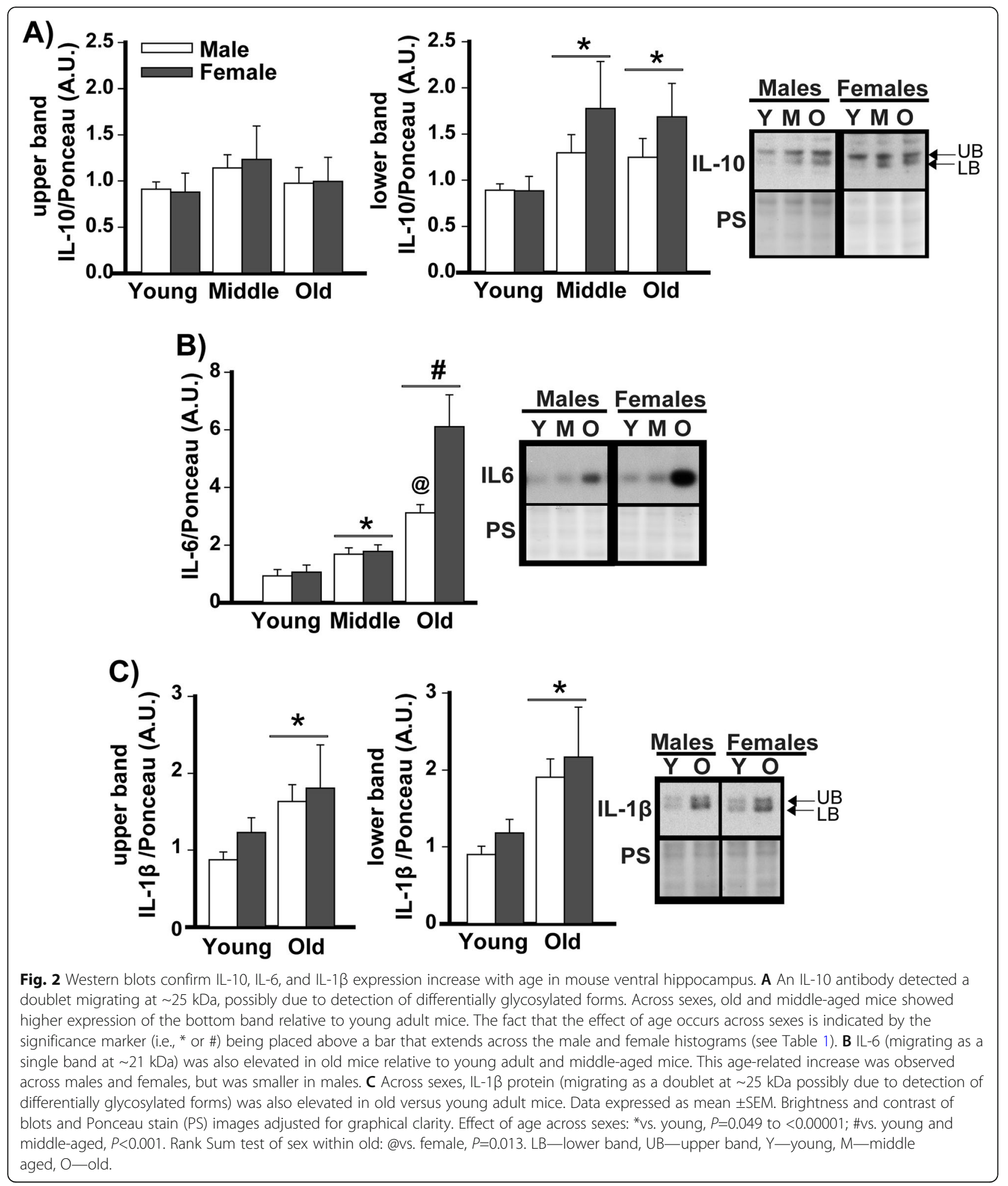

C57BL/6J mice. IL-6 expression increased with age in the dorsal hippocampus (Fig. 3A, see Table 1 for statistics; post hoc: young vs middle $P=0.005$, young vs. old $P<0.001$, middle vs. old $P<0.001$ ), prefrontal cortex (Fig. $3 \mathrm{C}$; Table 1), striatum (Fig. 3E; Table 1), and cerebellum of mice (Fig. 3G; Table 1; post hoc: middle age or old vs. young, $P<0.001)$. In contrast, IL- $1 \beta$ expression only increased with age in the dorsal hippocampus (Fig. 3B; Table 1). Unlike the ventral hippocampus, there was no age-related decrease in glycosylated/unglycosylated IL- 


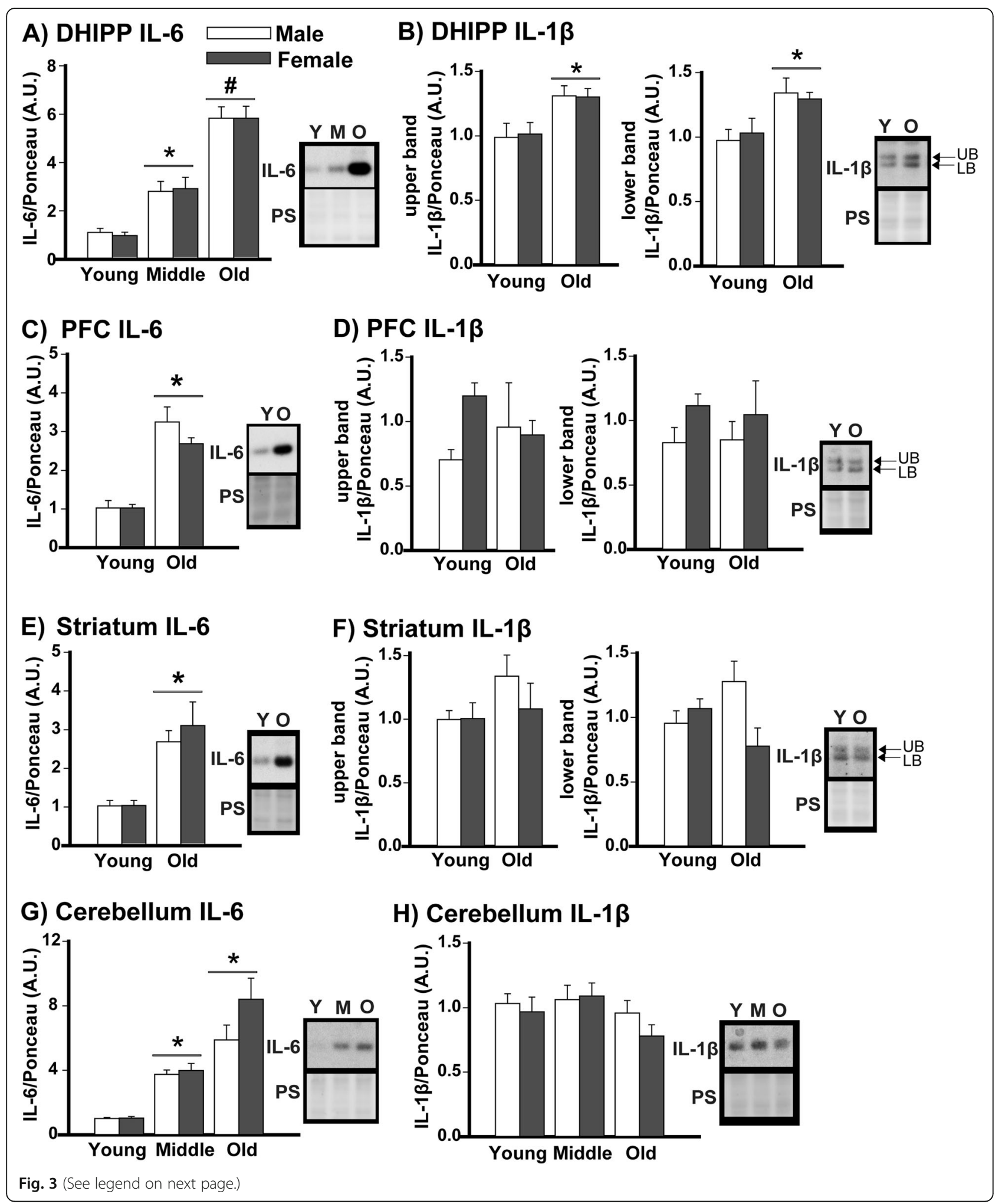




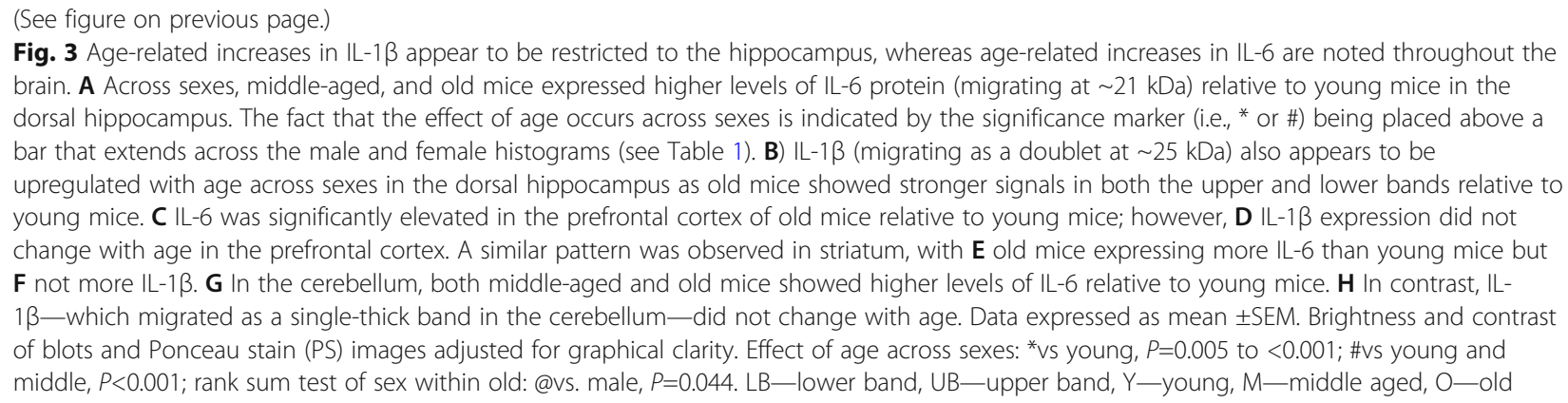

$1 \beta$ in the dorsal hippocampus (Figure S10C) or prefrontal cortex (Figure S10D), and females actually showed an increase in glycosylated/unglycosylated IL-1 $\beta$ in the striatum (Figure S10E). Also unlike the ventral hippocampus, males and females showed equivalent agerelated increases in IL-6 expression in the dorsal hippocampus, prefrontal cortex, striatum, and cerebellum suggesting the heightened age-related increases in IL-6 observed above in females are restricted to the ventral hippocampus in this mouse strain. Age-related increases in IL-6 expression outside of the hippocampus were confirmed in the second cohort of C57BL/6J mice with middle-aged mice $(n=5 \mathrm{M} / 6 \mathrm{~F})$ showing higher expression relative to young mice $(n=5 / \mathrm{sex})$ in the prefrontal cortex (young, $0.228 \pm 0.01$ A.U.; middle, $1.00 \pm 0.07$ A.U.; rank sum test: $T(10,11)=55.00, P<0.001$ ) and striatum (young, $0.275 \pm 0.03$ A.U.; middle, $1.00 \pm 0.07$ A.U.; rank sum test: $T(10,11)=45.00, P<0.001)$. These data together with the Bioplex data suggest that while the hippocampus exhibits a widespread upregulation of cytokines with age, other brain regions exhibit a more restricted upregulation.

\section{Western blots show age-related increases in IL- 6 are also observed in BALB/cJ mice and Brown Norway Rats}

To determine if the observed age-related increases in IL6 are conserved across mouse strains and rats, we measured IL-6 expression in the brains of young versus old $\mathrm{BALB} / \mathrm{cJ}$ mice and Brown Norway Rats. Relative to young $B A L B / c J$ mice, old $B A L B / c J$ mice express significantly higher levels of IL-6 protein in the ventral hippocampus, dorsal hippocampus, prefrontal cortex, striatum, and cerebellum (Fig. 4A-E). Visual inspection of the data suggests the age-related increases in IL-6 may be more prominent in the female vs male BALB/cJ mice in the ventral hippocampus, PFC, and striatum, but the study was not sufficiently powered for a formal analysis of sex as a factor. Old Brown Norway Rats also showed higher expression of IL-6 protein in the PFC and cerebellum relative to young rats (Fig. 5F-G), with females showing higher IL- 6 expression than males in the cerebellum (Table 1). Together, these data suggest that widespread age-related increases in IL-6 expression are conserved across species, are generally more pronounced in females, and are not tied to a single rearing environment.

\section{Age-related increases in IL- 6 are more pronounced in cytosolic versus membrane or nuclear fractions}

IL-6 can signal through multiple pathways, each of which has different functional consequences. Specifically, IL-6 signals via membrane-bound IL-6 receptors in the "classic" pathway to elicit anti-inflammatory responses and soluble IL-6 receptors in the "trans-signaling" pathway to elicit pro-inflammatory responses [51-53]. As such, we conducted biochemical fractionation on the ventral and dorsal hippocampus of young versus old C57BL/6J mice. In both ventral and dorsal hippocampus, we found age-related IL-6 increases occur in all fractions but that the magnitude of the age-related increase in cytosolic IL-6 was twice that observed in the membrane or nuclear fractions (Fig. 5; effect of a fraction within old: $F(2,14)=13.35, P<0.001$; post hoc: cytosolic vs. nuclear and membrane, $P \leq 0.001)$. Parsimoniously, this points to a predominantly pro-inflammatory consequence of these age-related increases.

\section{Discussion}

Here we showed that age-related increases in cytokine expression are pervasive in the ventral hippocampus of C57BL/6 mice, with 20 out of the 23 cytokines showing significantly greater expression in aged vs. young adult mice. The 20 cytokines upregulated with age included the pro-inflammatory cytokines IL- $1 \alpha$, IL-1 $\beta$, IL-2, IL-3, IL-6 (see further discussion below in paragraph 4), IL-9, IL-12p40, IL-12p70, IL-17, eotaxin, interfeuron $\delta, \mathrm{KC}$, MIP-1a, MIP-1b, rantes, and TNF $\alpha$ as well as the antiinflammatory cytokines IL-4, IL-10, IL-13, and G-CSF (Fig. 1). Cytokine expression levels also became much more strongly correlated in old mice (80 significant correlations) vs young mice (9 significant correlations (Fig. 1X, Tables S2 and S3), with a unique module/network of 11 highly intercorrelated cytokines emerging in old mice (IL-1 $\alpha$, IL-1 $\beta$, IL-3, IL-6, KL12p40, IL-13, IL17, KC, 


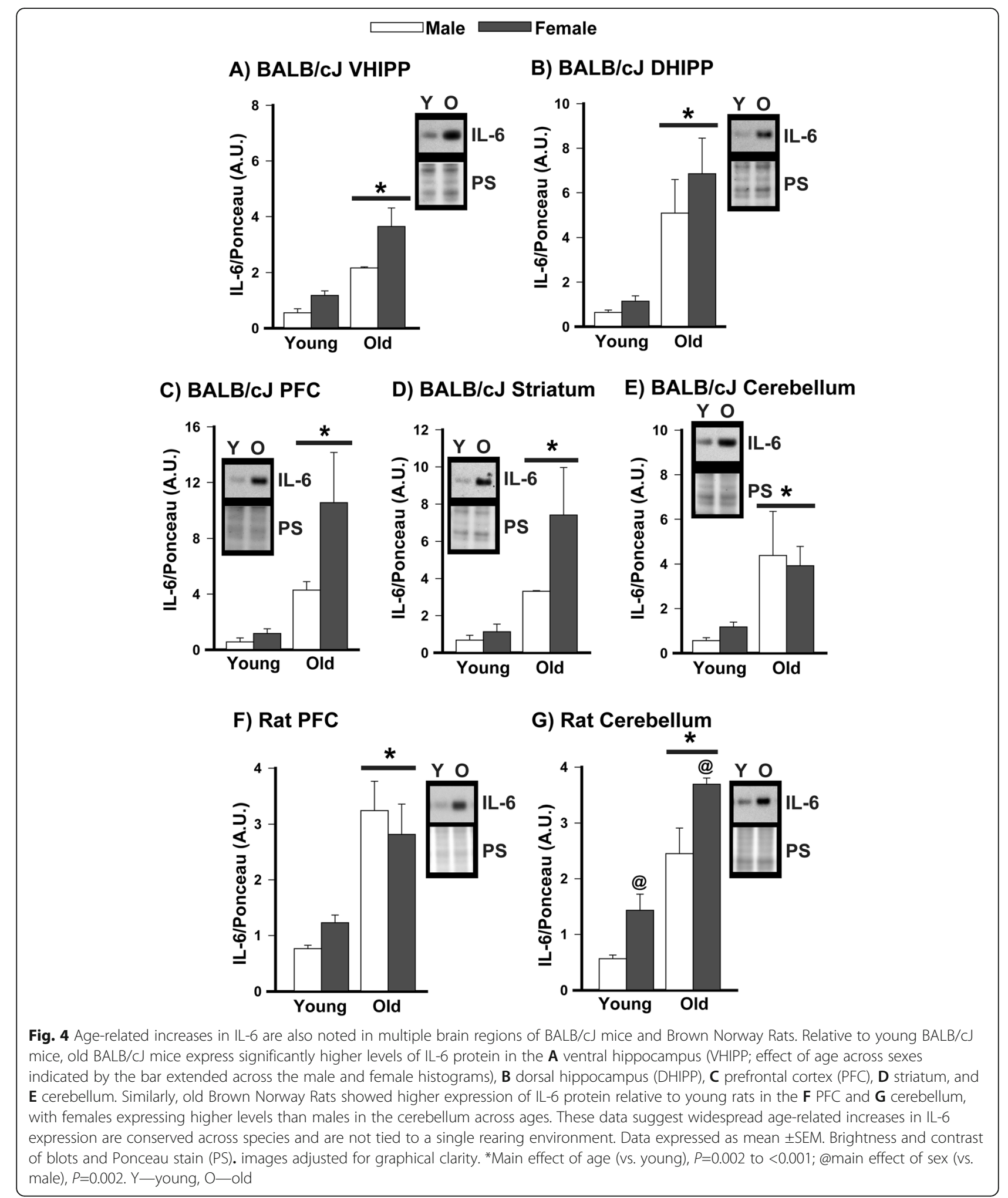

MCP-1, MIP-1b, and Rantes). It has been suggested that the identification of such disease-associated modules may be useful biomarkers for diagnosis or predicting patient outcomes and/or treatment responses (e.g., [50, 54,
55]). Further, IL-10 and IL-1 $\beta$ exhibited a shift from glycosylated to unglycosylated isoforms in the ventral hippocampus, suggesting even higher specific activity [56]. Interestingly, age-related increases in cytokine 

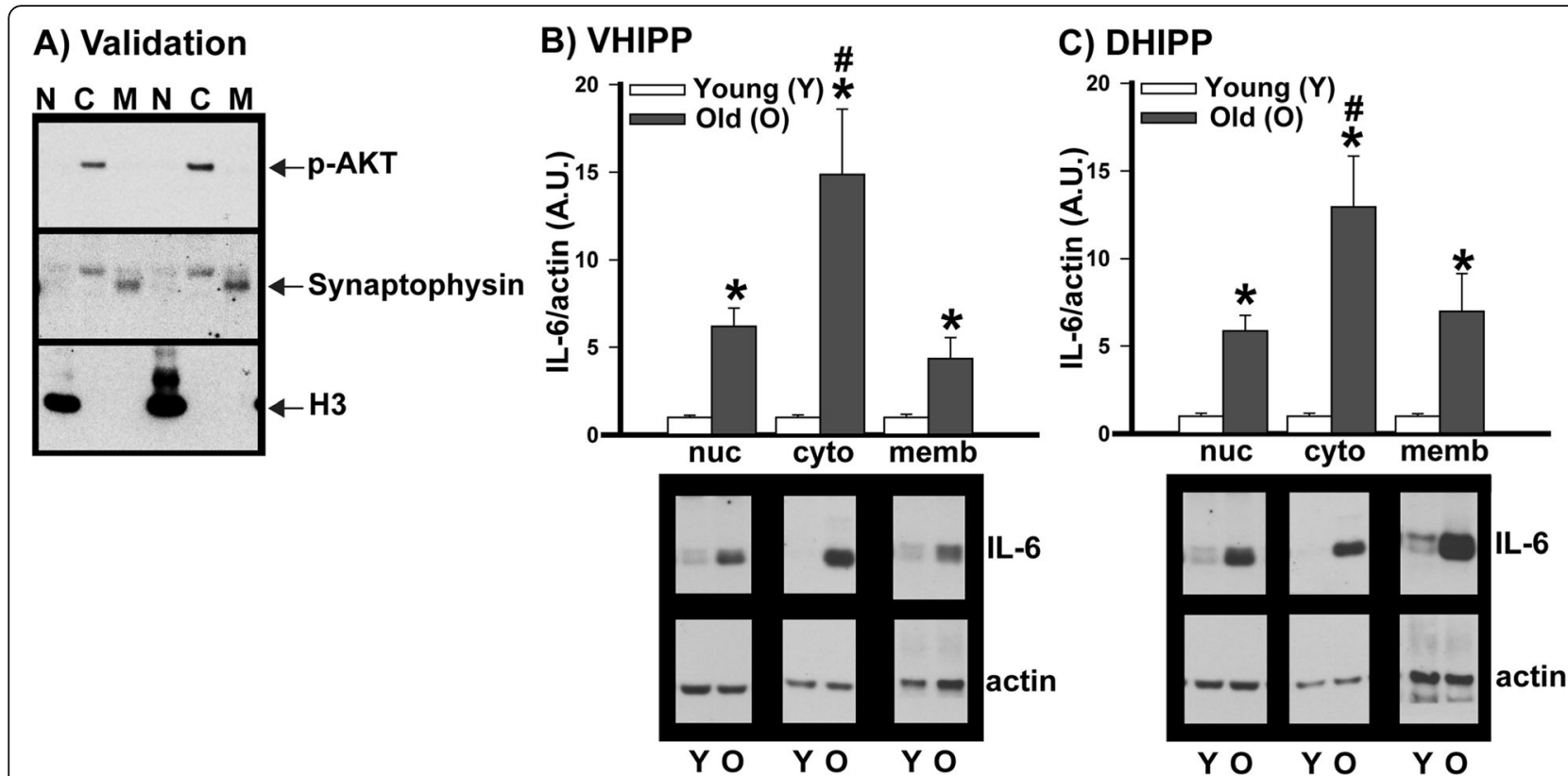

Fig. 5 Age-related increases in hippocampal IL-6 are more pronounced in cytosolic versus nuclear or membrane fractions. To determine if agerelated increases in IL-6 were more likely to impact the membrane-associated classical anti-inflammatory pathway or the soluble trans-signaling pro-inflammatory pathway, hippocampi from C57BL/6J mice were subjected to biochemical fractionation to separate proteins into nuclear ( $N$, nuc), cytosolic ( $\mathrm{C}$, cyto), and membrane ( $\mathrm{M}$, memb) fractions. A Validation of biochemically fractionated samples suggests minimal contamination of the nuclear fraction with unsheared cells as we find histone 3 in the nuclear fraction but not cytosol or membrane, pAKT enriched in the cytosol fraction, and synaptophysin in the membrane but not nuclear or cytosolic fraction. B In the ventral hippocampus (VHIPP), old mice showed higher expression of IL-6 relative to young mice in the nuclear, cytosolic, and membrane fractions. C The dorsal hippocampus (DHIPP) showed the same pattern with old mice expressing higher levels of IL-6 relative to young mice in the nuclear, cytosolic, and membrane fractions. Across the ventral and dorsal hippocampus, the age-related increases that were observed in the cytosolic fractions were approximately twice those observed in the nuclear and membrane fractions. Data expressed as mean \pm SEM. Brightness and contrast of blots adjusted for graphical clarity. Post hoc: \#vs nuclear and membrane, $P \leq 0.001$; *vs young, $P \leq 0.002$

expression outside of the hippocampus appear to be more discreet, with the prefrontal cortex, striatum, and cerebellum demonstrating an age-related increase in IL6 expression but not IL-1 $\beta$. Importantly, we found this widespread age-related increase in IL-6 is conserved across species, occurring in C57BL/6J mice, BALB/cJ mice, and Brown Norway rats. In select brain regions, the age-related increases in IL-6 were more pronounced in females relative to males, and biochemical fractionation suggests the age-related increases in IL-6 disproportionately target pro- vs. anti-inflammatory signaling cascades. Together, our data are consistent with pathway analyses that suggest age-related changes in inflammation- and immune-related gene expression are more pronounced in the hippocampus compared to other brain regions and more pronounced in females versus males $[7,8,57]$.

There have been many inconsistencies in the literature with regard to reports of age-related changes-or lack thereof-in cytokine protein expression. Our results are consistent with several past studies showing age-related increases in basal IL- $1 \beta$ protein in the hippocampus of a variety of naturally aging mice and rats [23-28], but not in brain regions outside of the hippocampus [22, 23, 3032 , 37]. That said, our results differ from several studies specifically using the F344xBN rats from the NIA colony that found no effect of age on basal IL-1 $\beta$ protein expression; although they did report age-related exacerbation of IL-1 $\beta$ protein induction caused by a high-fat diet, Escherichia coli infection or surgery [22, 30-32]. As noted above, findings around IL-6 are particularly diverse, with many studies reporting age-related increases in basal IL-6 expression in the brains of naturally aging rodents [21, 33, 40-42] and several others finding no age-related changes [22, 23, 37]. Inconsistencies in the literature around IL- 6 cannot be so easily explained by differences in the strains used or the specific brain region examined. For example, one study employing C57BL/6J mice found age-related increases in IL-6 protein expression in the cortex as did we [34]; however, the effect in another study failed to reach statistical significance [23]. Such inconsistencies in the literature may be related to differential sensitivities of antibodies. Indeed, we found Femto chemiluminescence substrate was needed to reliably detect cytokine expression in our whole-tissue homogenates. Differing environmental 
factors across labs may also contribute to reported inconsistencies. For example, diet, and other environmental factors have been shown to preferentially upregulate cytokine expression in aged vs. young adult brains [11, 12, 35-37]. Differences in ambient temperatures from facility to facility may even be to blame since higher temperatures can increase the expression of cytokines [58] or increase the transport of cytokines from the periphery into the brain [59]. The age-related increases in IL-6 we have measured are the most robust biochemical finding ever observed in our lab. They have been detected using 2 different IL- 6 antibodies, using tissue from multiple brain regions from multiple cohorts of mouse strains raised at different times in our facility and even tissue from rats raised in a different animal facility. That said, we cannot rule out the possibility that our ability to detect such reliable age-related increases in IL6 expression may be directly related to environmental factors present in the animal facility at the University of South Carolina at the time of tissue harvesting, since the rats obtained from the NIA colony did have to habituate for 1 week prior to experimentation.

It will be of interest to future studies to determine the cell type and mechanism driving the region-specific changes in cytokine expression described herein. Microglia release a myriad of cytokines [60] but cytokines can also be released by brain endothelial cells, astrocytes, and neurons as well [42, 60,61]. Neurons can further regulate cytokine levels by releasing signals that either activate (i.e., "on signals") or deactivate/inhibit microglia (i.e., "off signals") [62]. Our findings suggest that agerelated increases in the hippocampus may be more extensive than those in the prefrontal cortex, striatum, or cerebellum. This increased sensitivity of the hippocampus is consistent with the fact that the hippocampus is one of the brain regions most populated with microglia [13].

Upon biochemical fractionation of the hippocampus, we found that IL-6 expression was increased with age in all fractions but that the magnitude of the increase was far greater in the cytosolic versus nuclear or membrane fraction. We cannot completely exclude the possibility that expression observed in the nuclear fraction reflects contamination by unsheared cells; however, the fact that we do not find substantial expression of the cytosolic marker pAKT or the membrane marker synaptophysin in the nuclear fractions suggests such contamination of our nuclear fraction is minimal. Even if the IL- 6 expression found in the nuclear fraction actually reflects contamination from the membrane of unsheared cells, it would not change the conclusion drawn from the experiment-that is, that the magnitude of age-related increases is larger in the soluble fraction. This pattern has important functional implications. IL-6 can signal via membrane-bound IL- 6 receptors in the "classic" pathway to elicit anti-inflammatory responses, or IL-6 can signal via soluble IL-6 receptors in the "trans-signaling" pathway to elicit pro-inflammatory responses [51, 52]. The fact that age-related increases in hippocampal IL-6 are far greater in the cytosolic versus membrane fraction points to a proinflammatory response. Indeed, increased activation of IL- 6 trans-signaling in the brain has been implicated in several inflammatory age-related diseases of the nervous system, including Alzheimer's and Parkinson's Disease (c.f., [52]). The fact that we observe age-related increases in the nuclear fraction suggests IL6 may also participate in a non-canonical cytokine signaling pathway whereby cytokine-bound receptors are internalized to the cytosol for transport to the nucleus (e.g., [63]). It will be of interest to future studies to understand if targeting soluble vs membrane IL-6 receptors may prove therapeutic for the aging brain $[64,65]$.

Age-related increases in pro-inflammatory cytokines are thought to be detrimental since higher expression of pro-inflammatory cytokines in humans and rodents correlates with deficits in cognitive function, synaptic plasticity, neurogenesis, and neurotrophic factor expression [9, 14, 25, 27, 30, 32, 66-73]. In contrast, an age-related increase in anti-inflammatory cytokines is thought to be protective, while their loss impairs plasticity and cognition [26, 74-77]. Here, we found that pro- and antiinflammatory cytokines were upregulated largely in parallel with each other (Table 2). Further, the module of highly intercorrelated cytokines that emerged with age (i.e., IL-1 $\alpha$, IL-1 $\beta$, IL-3, IL-6, KL12p40, IL-13, IL17, KC, MCP-1, MIP-1b, and Rantes) included both pro- and anti-inflammatory pathway members. Together, this suggests an attempt of anti-inflammatory pathways to compensate for the dysregulation of pro-inflammatory pathways. It is likely that the widespread age-related increase in IL-6 noted herein is detrimental since the majority of studies suggest elevated expression impairs cognitive function $([66,67,78,79]$, but see [42]). As such, therapeutics that restore cytokine signaling may prove beneficial in the treatment of age-related disorders.

It is noteworthy that robust and consistent sex differences were observed in the present study [80]. Whereas the female-aged brain was biased towards exaggerated inflammation relative to the male brain, no differences between males and females were evident in young or middle-aged mice. Although the majority of these studies were not powered to allow for statistical sex-based conclusions, the exacerbated neuroinflammation observed within the aging female brain was reliable and robust. For example, 14/17 old females exhibited VHIPP IL-6 levels that exceeded the mean value measured in old males. These data are in line with other studies indicating that neuroinflammation accumulates in the aged 
female hippocampus to a greater extent than males [57] and highlights a potential mechanism whereby females display faster age-related cognitive decline than men [81] and higher rates of Alzheimer's disease [82]. It will be of interest to future studies to understand the basis for these augmented female responses. Both female and male hormones fluctuate over time and change with age in rodents, with age-related decreases in pulsatile $\mathrm{GnRH}$ observed in male rodents and a multiplicity of ovarian states observed in aging female rodents (i.e., estropause in a persistent estrus phase, estropause in a persistent diestrus phase, or irregular cycling) [83-87]. Such changes in ovarian aging status have been shown to influence inflammatory and metabolic gene expression in the rat hippocampus, albeit not differentially in the ventral versus dorsal hippocampus [88]. Further, a number of peripheral inflammatory diseases increase with time-some of which occur differentially in males versus females and some of which elicit different cytokine profiles in males versus females (e.g., $[89,90])$. The fact that we did not track hormonal status or peripheral pathology may be considered a weakness of the present study. That said, it is not intuitive how global changes in blood cytokine levels triggered by hormones or tumors would elicit such brain region-specific effects (i.e., ventral but not dorsal hippocampus) or cytokine-specific sex effects (i.e., IL-6 but not IL-1 or IL-10). Whatever their basis, efforts to therapeutically target cytokine signaling should give serious consideration to these sex differences, particularly given that anti-inflammatory therapeutic responses [91] and the half-life of cytokine antagonists [92] differ in males versus females.

A number of therapeutic avenues are currently being pursued to target age-related increases in neuroinflammation. Natural products containing resveratrol have been shown to attenuate serum IL- 6 and TNF $\alpha$ levels in healthy older adults along with memory retention and hippocampal functional connectivity $[93,94]$. Other antioxidants have reduced TNF $\alpha$ and IL- $1 \beta$ mRNA and protein expression in the brains of senescenceaccelerated mouse models [95]. Reported effects of melatonin are mixed with 1 study reporting reduced TNF $\alpha$, IL-1 $\beta$, and IL- 6 protein expression in the hippocampus [21] and the other reporting no effect on age-related increases in TNF $\alpha$ and worsening of age-related increases in brain IL-1 $\alpha$ [96]. Probiotics not only lowered TNF $\alpha$ and MCP1 protein expression in the serum while increasing IL-10 protein expression, but also improved cognition in a senescence-accelerated mouse model (males and females, [97]). Biological approaches have also been taken to overcome the damaging effects of pro-inflammatory cytokines, including infusion of receptor antagonists or anti-inflammatory cytokines [26, 28, $32,69,74,76,77,98]$. Of particular note-given our biochemical fractionation data-biologics that inhibit IL6 trans-signaling specifically are being developed in the context of a number of inflammatory diseases (c.f., [52]). Finally, behavioral therapeutic approaches, such as mindfulness training or exercise, have also shown promise in attenuating age-related increases in IL-1 $\beta$ and IL6 , at least in males [99-102] and cognitive behavioral therapy has been shown to boost immune function across sexes by reducing proinflammatory molecules and improving immune cell counts [103]. Importantly, peripheral markers of inflammation and immune activation may prove viable patient-selection biomarkers for such clinical trials given that several studies demonstrate parallel changes in the brain and blood or saliva $[7,8,33]$ as well as correlations between elevated cytokine expression in the serum and reduced cognitive function [104].

\section{Conclusion}

Taken together, our findings suggest that age-related increases in cytokines are more pronounced in the hippocampus compared to other brain regions and can be more pronounced in females versus males depending on the brain region, genetic background, and cytokine examined. As such, it will be important to consider sex differences in the underlying pathology as well as pharmacokinetics/pharmacodynamics when considering cytokines as therapeutic targets in the context of agerelated disease.

\section{Abbreviations}

FDR: False rate discovery; G-CSF: Granulocyte colony-stimulating factor; GMCSF: Granulocyte-macrophage colony-stimulating factor; IL: Interleukin; IFN: Interfeuron; MCP1: Monocyte chemoattractant protein 1;

MIP: Macrophage inflammatory protein; PFC: Prefrontal cortex; TNF: Tumor necrosis factor

\section{Supplementary Information}

The online version contains supplementary material available at https://doi. org/10.1186/s12974-021-02252-6.

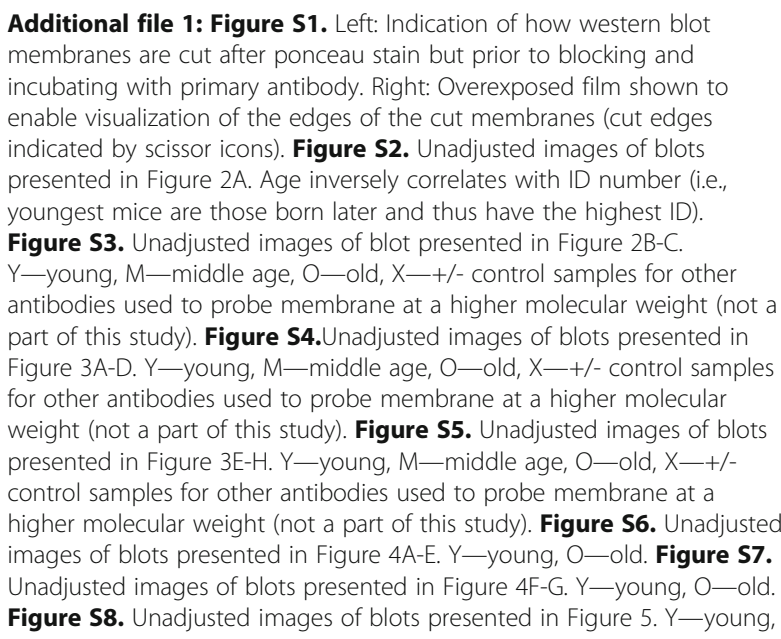


O-old, X-+/- control samples for other antibodies used to probe membrane at a higher molecular weight (not a part of this study). Figure $\mathbf{S 9 .}$ Data from Figure 1 replotted by sex. The bar placed above the old males and females with the asterisk on top is intended to reflect the main effect of age (i.e., there were insufficient $\mathrm{n} / \mathrm{se}$ to warrant an analyses of age $x$ sex). Figure S10. Ratios of glycosylated/unglycosylated cytokines exhibit age-related changes in select brain regions. IL-10 and IL-1 $\beta$ data from Figures 2 and 3 were re-expressed as a ratio of the density of the top band (i.e., presumed glycosylated isoform) over the density of the bottom band (i.e., presumed unglycosylated isoform). A) In ventral hippocampus (VHIPP), the ratio of glycosylated/unglycosylated IL-10 decreased with age (effect of age: $F(2,28)=21.19, P<0.001$; Post hoc: young vs. middle $P=$ 0.002 , young vs. old $P<0.001$, and middle vs. old $P=0.033$ ). Although this shift was somewhat more pronounced in females, the effect did not reach the level of statistical significance (effect of sex: $F(1,28)=3.30, P=$ 0.08). B) In VHIPP, the ratio of glycosylated/unglycosylated IL-1 $\beta$ similarly decreased with age (effect of age: $F(1,23)=16.09, P<0.001$ ). In contrast, the ratio of glycosylated/unglycosylated IL-1 1 remained stable in C) dorsal hippocampus (DHIPP) and D) prefrontal cortex (PFC), and E) actually increased in striatum of females (2-Way ANOVA failed normality; Rank Sum Test females: $T(6,7)=27.00, P=0.035$; student t-test males: $\mathrm{t}(20)=0.03, \mathrm{P}=$ $0.98)$. *vs. young only, $\mathrm{P}=0.002$ to $<0.001$; \#vs young and middle, $\mathrm{P}=0.033$ to $<0.001$

Additional file 2: Table S1. Cytokine expression detected in young adult, middle-aged and old ventral hippocampus ( $n=8 /$ group) when using $0.275 \mathrm{mg}$ total protein in the Biorad Bioplex assay.

Additional file 3: TableS2. Correlational analyses of Bioplex data shown in Figure 1 reveals cytokines are largely uncorrelated in ventral hippocampus of young mice (shown right; significant FDR-P values bolded) but approximately half of these cytokines become highly correlated with each other in old mice (shown left; gray highlighting indicates correlations that are significant in both old and young mice).

Additional file 4: Table S3. A chart of results from correlational analyses shown in Table S2 (significant $r$, 1; non-significant $r$. 0) reveals a module of 11 highly intercorrelated cytokines (highlighted in yellow; red text indicates rare failures in module members correlating with each other).

\section{Acknowledgements}

The authors would like to sincerely thank Marlee Poole and the animal husbandry staff for taking such great care of our colony.

\section{Authors' contributions}

$L P, S B, S B$, and NG collected/analyzed Western data and wrote parts of the manuscript. JF and SKW collected the Bioplex data and wrote/edited parts of the manuscript. MPK conceptualized the study, analyzed data, and wrote/ edited the manuscript. The authors read and approved the final manuscript.

\section{Funding}

This work was funded by start-up funds from the University of Maryland School of Medicine (MPK) and grants from the NIA (R01AG061200, MPK) and NIMH (R01MH101130, MPK; R01MH113892, SKW). The content of this manuscript is solely the responsibility of the authors and does not necessarily represent the official views of the National Institutes of Health.

\section{Availability of data and materials}

The datasets used and/or analyzed during the current study are available from the corresponding author on reasonable request.

\section{Declarations}

\section{Ethics approval and consent to participate}

Experiments were carried out in accordance with the National Institutes of Health Guide for the Care and Use of Laboratory Animals (Pub 85-23, revised 1996) and were fully approved by the Institutional Animal Care and Use Committee of the University of South Carolina and the University of Maryland, Baltimore.

\section{Consent for publication}

Not applicable.

\section{Competing interests}

The authors declare that they have no competing interests.

\section{Author details}

${ }^{1}$ Pharmacology, Physiology \& Neuroscience, University of South Carolina School of Medicine, 6439 Garners Ferry Rd, Columbia, SC 29209, USA.

${ }^{2}$ Department of Anatomy \& Neurobiology, University of Maryland School of Medicine, 20 Penn St, HSFII Rm 216, Baltimore, MD 21201, USA. ${ }^{3}$ Center for Research on Aging, University of Maryland School of Medicine, 20 Penn St, HSFII Rm 216, Baltimore, MD 21201, USA.

Received: 6 May 2021 Accepted: 25 August 2021

Published online: 22 September 2021

\section{References}

1. Harada CN, Natelson Love MC, Triebel KL. Normal cognitive aging. Clin Geriatr Med. 2013;29(4):737-52. https://doi.org/10.1016/j.cger.2013.07.002.

2. Wyss-Coray T. Ageing, neurodegeneration and brain rejuvenation. Nature. 2016;539(7628):180-6. https://doi.org/10.1038/nature20411.

3. Fjell AM, McEvoy L, Holland D, Dale AM, Walhovd KB. Alzheimer's Disease Neuroimaging I: What is normal in normal aging? Effects of aging, amyloid and Alzheimer's disease on the cerebral cortex and the hippocampus. Prog Neurobiol. 2014;117:20-40. https://doi.org/10.1016/.jpneurobio.2014.02.004.

4. Pini L, Pievani M, Bocchetta M, Altomare D, Bosco P, Cavedo E, et al. Brain atrophy in Alzheimer's disease and aging. Ageing Res Rev. 2016;30:25-48. https://doi.org/10.1016/j.arr.2016.01.002.

5. Liang KJ, Carlson ES. Resistance, vulnerability and resilience: a review of the cognitive cerebellum in aging and neurodegenerative diseases. Neurobiol Learn Mem. 2020;170:106981. https://doi.org/10.1016/j.nlm.2019.01.004.

6. Bettio LEB, Rajendran L, Gil-Mohapel J. The effects of aging in the hippocampus and cognitive decline. Neurosci Biobehav Rev. 2017;79:66-86. https://doi.org/10.1016/j.neubiorev.2017.04.030.

7. Berchtold NC, Cribbs DH, Coleman PD, Rogers J, Head E, Kim R, et al. Gene expression changes in the course of normal brain aging are sexually dimorphic. Proc Natl Acad Sci U S A. 2008;105(40):15605-10. https://doi. org/10.1073/pnas.0806883105.

8. Cribbs DH, Berchtold NC, Perreau V, Coleman PD, Rogers J, Tenner AJ, et al. Extensive innate immune gene activation accompanies brain aging, increasing vulnerability to cognitive decline and neurodegeneration: a microarray study. J Neuroinflammation. 2012;9(1):179. https://doi.org/10.11 86/1742-2094-9-179.

9. Barrientos RM, Kitt MM, Watkins LR, Maier SF. Neuroinflammation in the normal aging hippocampus. Neuroscience. 2015;309:84-99. https://doi.org/1 0.1016/j.neuroscience.2015.03.007.

10. Sparkman NL, Johnson RW. Neuroinflammation associated with aging sensitizes the brain to the effects of infection or stress. Neuroimmunomodulation. 2008;15(4-6):323-30. https://doi.org/10.1159/0001 56474.

11. Chen J, Buchanan JB, Sparkman NL, Godbout JP, Freund GG, Johnson RW. Neuroinflammation and disruption in working memory in aged mice after acute stimulation of the peripheral innate immune system. Brain Behav Immun. 2008:22(3):301-11. https://doi.org/10.1016/j.bbi.2007.08.014.

12. Godbout JP, Chen J, Abraham J, Richwine AF, Berg BM, Kelley KW, et al. Exaggerated neuroinflammation and sickness behavior in aged mice following activation of the peripheral innate immune system. FASEB J. 2005; 19(10):1329-31. https://doi.org/10.1096/fj.05-3776fje.

13. von Bernhardi R, Tichauer JE, Eugenin J. Aging-dependent changes of microglial cells and their relevance for neurodegenerative disorders. J Neurochem. 2010;112(5):1099-114. https://doi.org/10.1111/j.1471-4159.2009. 06537.x.

14. Patterson SL. Immune dysregulation and cognitive vulnerability in the aging brain: interactions of microglia, IL-1 beta, BDNF and synaptic plasticity. Neuropharmacology. 2015;96(Pt A):11-8. https://doi.org/10.1016/j.neuropha rm.2014.12.020.

15. Diniz LP, Matias I, Siqueira M, Stipursky J, Gomes FCA. Astrocytes and the TGF-beta1 pathway in the healthy and diseased brain: a double-edged sword. Mol Neurobiol. 2019;56(7):4653-79. https://doi.org/10.1007/s12035-01 8-1396-y. 
16. Weber M, Wu T, Hanson JE, Alam NM, Solanoy H, Ngu H, Lauffer BE, Lin HH, Dominguez SL, Reeder J, Tom J, Steiner P, Foreman O, Prusky GT, ScearceLevie K: Cognitive deficits, changes in synaptic function, and brain pathology in a mouse model of normal aging $(1,2,3)$. eNeuro 2015, 2, 5, ENEURO.0047, ENEU15.2015, DOI: https://doi.org/10.1523/ENEURO.0047-15.2 015 .

17. Bodles AM, Barger SW. Cytokines and the aging brain - what we don't know might help us. Trends Neurosci. 2004;27(10):621-6. https://doi.org/1 0.1016/j.tins.2004.07.011.

18. Wingo AP, Dammer EB, Breen MS, Logsdon BA, Duong DM, Troncosco JC, et al. Large-scale proteomic analysis of human brain identifies proteins associated with cognitive trajectory in advanced age. Nat Commun. 2019; 10(1):1619. https://doi.org/10.1038/s41467-019-09613-z.

19. Di Benedetto S, Muller L, Wenger E, Duzel S, Pawelec G. Contribution of neuroinflammation and immunity to brain aging and the mitigating effects of physical and cognitive interventions. Neurosci Biobehav Rev. 2017;75: 114-28. https://doi.org/10.1016/i.neubiorev.2017.01.044.

20. Barroeta-Espar I, Weinstock LD, Perez-Nievas BG, Meltzer AC. Siao Tick Chong M, Amaral AC, Murray ME, Moulder KL, Morris JC, Cairns NJ, et al: Distinct cytokine profiles in human brains resilient to Alzheimer's pathology. Neurobiol Dis. 2019;121:327-37. https://doi.org/10.1016/j.nbd.2018.10.009.

21. Permpoonputtana K, Tangweerasing P, Mukda S, Boontem P, Nopparat C, Govitrapong P. Long-term administration of melatonin attenuates neuroinflammation in the aged mouse brain. EXCLI J. 2018;17:634-46. https://doi.org/10.17179/excli2017-654.

22. Spencer SJ, D'Angelo H, Soch A, Watkins LR, Maier SF, Barrientos RM. Highfat diet and aging interact to produce neuroinflammation and impair hippocampal- and amygdalar-dependent memory. Neurobiol Aging. 2017; 58:88-101. https://doi.org/10.1016/j.neurobiolaging.2017.06.014.

23. McLinden KA, Kranjac D, Deodati LE, Kahn M, Chumley MJ, Boehm GW. Age exacerbates sickness behavior following exposure to a viral mimetic. Physiol Behav. 2012;105(5):1219-25. https://doi.org/10.1016/j.physbeh.2011.04.024.

24. Chen $Y$, Yin M, Cao X, Hu G, Xiao M. Pro- and anti-inflammatory effects of high cholesterol diet on aged brain. Aging Dis. 2018;9(3):374-90. https://doi. org/10.14336/AD.2017.0706.

25. Griffin R, Nally R, Nolan Y, McCartney Y, Linden J, Lynch MA. The age-related attenuation in long-term potentiation is associated with microglial activation. J Neurochem. 2006;99(4):1263-72. https://doi.org/10.1111/j.14 71-4159.2006.04165.x.

26. Nolan Y, Maher FO, Martin DS, Clarke RM, Brady MT, Bolton AE, et al. Role of interleukin-4 in regulation of age-related inflammatory changes in the hippocampus. J Biol Chem. 2005;280(10):9354-62. https://doi.org/10.1074/ jbc.M412170200.

27. Murray CA, Lynch MA. Evidence that increased hippocampal expression of the cytokine interleukin-1 beta is a common trigger for age- and stressinduced impairments in long-term potentiation. J Neurosci. 1998;18(8): 2974-81. https://doi.org/10.1523/JNEUROSCl.18-08-02974.1998.

28. Maher FO, Nolan Y, Lynch MA. Downregulation of IL-4-induced signalling in hippocampus contributes to deficits in LTP in the aged rat. Neurobiol Aging. 2005;26(5):717-28. https://doi.org/10.1016/j.neurobiolaging.2004.07.002.

29. Tha KK, Okuma Y, Miyazaki H, Murayama T, Uehara T, Hatakeyama R, et al. Changes in expressions of proinflammatory cytokines IL-1beta, TNF-alpha and IL-6 in the brain of senescence accelerated mouse (SAM) P8. Brain Res. 2000;885(1):25-31. https://doi.org/10.1016/S0006-8993(00)02883-3.

30. Barrientos RM, Higgins EA, Biedenkapp JC, Sprunger DB, Wright-Hardesty KJ, Watkins LR, et al. Peripheral infection and aging interact to impair hippocampal memory consolidation. Neurobiol Aging. 2006;27(5):723-32. https://doi.org/10.1016/j.neurobiolaging.2005.03.010.

31. Barrientos RM, Frank MG, Hein AM, Higgins EA, Watkins LR, Rudy JW, et al. Time course of hippocampal IL-1 beta and memory consolidation impairments in aging rats following peripheral infection. Brain Behav Immun. 2009;23(1):46-54. https://doi.org/10.1016/j.bbi.2008.07.002

32. Barrientos RM, Hein AM, Frank MG, Watkins LR, Maier SF. Intracisternal interleukin-1 receptor antagonist prevents postoperative cognitive decline and neuroinflammatory response in aged rats. J Neurosci. 2012;32(42): 14641-8. https://doi.org/10.1523/JNEUROSCI.2173-12.2012.

33. Ye SM, Johnson RW. Increased interleukin- 6 expression by microglia from brain of aged mice. J Neuroimmunol. 1999;93(1-2):139-48. https://doi.org/1 0.1016/S0165-5728(98)00217-3.

34. Prechel MM, Halbur L, Devata S, Vaidya AM, Young MR. Increased interleukin-6 production by cerebral cortical tissue of adult versus young mice. Mech Ageing Dev. 1996;92(2-3):185-94. https://doi.org/10.1016/S00476374(96)01833-7.

35. Buchanan JB, Sparkman NL, Chen J, Johnson RW. Cognitive and neuroinflammatory consequences of mild repeated stress are exacerbated in aged mice. Psychoneuroendocrinology. 2008;33(6):755-65. https://doi. org/10.1016/j.psyneuen.2008.02.013.

36. Sandhir R, Puri V, Klein RM, Berman NE. Differential expression of cytokines and chemokines during secondary neuron death following brain injury in old and young mice. Neurosci Lett. 2004;369(1):28-32. https://doi.org/10.101 6/j.neulet.2004.07.032.

37. d'Avila JC, Siqueira LD, Mazeraud A, Azevedo EP, Foguel D, Castro-FariaNeto $\mathrm{HC}$, et al. Age-related cognitive impairment is associated with longterm neuroinflammation and oxidative stress in a mouse model of episodic systemic inflammation. J Neuroinflammation. 2018;15(1):28. https://doi.org/1 0.1186/s12974-018-1059-y.

38. Sierra A, Gottfried-Blackmore AC, McEwen BS, Bulloch K. Microglia derived from aging mice exhibit an altered inflammatory profile. Glia. 2007:55(4): 412-24. https://doi.org/10.1002/glia.20468.

39. Perez SD, Du K, Rendeiro C, Wang L, Wu Q, Rubakhin SS, et al. A unique combination of micronutrients rejuvenates cognitive performance in aged mice. Behav Brain Res. 2017;320:97-112. https://doi.org/10.1016/j.bbr.201 6.11.019.

40. Ye SM, Johnson RW. An age-related decline in interleukin-10 may contribute to the increased expression of interleukin- 6 in brain of aged mice. Neuroimmunomodulation. 2001;9(4):183-92. https://doi.org/10.1159/ 000049025.

41. Ye SM, Johnson RW. Regulation of interleukin-6 gene expression in brain of aged mice by nuclear factor kappaB. J Neuroimmunol. 2001;117(1-2):87-96. https://doi.org/10.1016/S0165-5728(01)00316-2.

42. Reyes TM, Fabry Z, Coe CL. Brain endothelial cell production of a neuroprotective cytokine, interleukin-6, in response to noxious stimuli. Brain Res. 1999;851(1-2):215-20. https://doi.org/10.1016/S0006-8993(99)02189-7.

43. Palomera-Avalos V, Grinan-Ferre C, Izquierdo V, Camins A, Sanfeliu C, Pallas M. Metabolic stress induces cognitive disturbances and inflammation in aged mice: protective role of resveratrol. Rejuvenation Res. 2017;20(3):20217. https://doi.org/10.1089/rej.2016.1885.

44. Blackwell BN, Bucci TJ, Hart RW, Turturro A. Longevity, body weight, and neoplasia in ad libitum-fed and diet-restricted C57BL6 mice fed $\mathrm{NIH}-31$ open formula diet. Toxicol Pathol. 1995;23(5):570-82. https://doi.org/10.11 77/019262339502300503

45. Finnell JE, Lombard CM, Melson MN, Singh NP, Nagarkatti M, Nagarkatti $P$, et al. The protective effects of resveratrol on social stress-induced cytokine release and depressive-like behavior. Brain Behav Immun. 2017;59:147-57. https://doi.org/10.1016/j.bbi.2016.08.019.

46. Finnell JE, Moffitt CM, Hesser LA, Harrington E, Melson MN, Wood CS, Wood SK: The contribution of the locus coeruleus-norepinephrine system in the emergence of defeat-induced inflammatory priming. Brain Behav Immun. 2019;79:102-13.

47. Patel NS, Klett J, Pilarzyk K, Lee DI, Kass D, Menniti FS, et al. Identification of new PDE9A isoforms and how their expression and subcellular compartmentalization in the brain change across the life span. Neurobiol Aging. 2018;65:217-34. https://doi.org/10.1016/j.neurobiolaging.2018.01.019.

48. Kelly MP, Adamowicz W, Bove S, Hartman AJ, Mariga A, Pathak G, et al. Select 3',5'-cyclic nucleotide phosphodiesterases exhibit altered expression in the aged rodent brain. Cell Signal. 2014;26(2):383-97. https://doi.org/10.1 016/j.cellsig.2013.10.007.

49. Pilarzyk K, Klett J, Pena EA, Porcher L, Smith AJ, Kelly MP. Loss of function of phosphodiesterase 11A4 shows that recent and remote long-term memories can be uncoupled. Curr Biol. 2019;29(14):2307-21 e2305. https:// doi.org/10.1016/j.cub.2019.06.018.

50. Cohen L, Fiore-Gartland A, Randolph AG, Panoskaltsis-Mortari A, Wong SS, Ralston J, et al. A modular cytokine analysis method reveals novel associations with clinical phenotypes and identifies sets of co-signaling cytokines across influenza natural infection cohorts and healthy controls. Front Immunol. 2019;10:1338. https://doi.org/10.3389/fimmu.2019.01338.

51. Campbell IL, Erta M, Lim SL, Frausto R, May U, Rose-John S, et al. Transsignaling is a dominant mechanism for the pathogenic actions of interleukin-6 in the brain. J Neurosci. 2014;34(7):2503-13. https://doi.org/10.1 523/JNEUROSCI.2830-13.2014.

52. Rothaug M, Becker-Pauly C, Rose-John S. The role of interleukin-6 signaling in nervous tissue. Biochim Biophys Acta. 1863;2016(6):1218-27. https://doi. org/10.1016/j.bbamcr.2016.03.018. 
53. Escrig A, Canal C, Sanchis P, Fernandez-Gayol O, Montilla A, Comes G, et al. IL-6 trans-signaling in the brain influences the behavioral and physiopathological phenotype of the Tg2576 and 3xTgAD mouse models of Alzheimer's disease. Brain Behav Immun. 2019;82:145-59. https://doi.org/1 0.1016/j.bbi.2019.08.005.

54. Mudd PA, Crawford JC, Turner JS, Souquette A, Reynolds D, Bender D, et al. Distinct inflammatory profiles distinguish COVID-19 from influenza with limited contributions from cytokine storm. Sci Adv. 2020;6(50):eabe3024. https://doi.org/10.1126/sciadv.abe3024.

55. Gelfo V, Rodia MT, Pucci M, Dall'Ora M, Santi S, Solmi R, et al. A module of inflammatory cytokines defines resistance of colorectal cancer to EGFR inhibitors. Oncotarget. 2016;7(44):72167-83. https://doi.org/10.18632/oncota rget. 12354.

56. Livi GP, Lillquist JS, Miles LM, Ferrara A, Sathe GM, Simon PL, et al. Secretion of $\mathrm{N}$-glycosylated interleukin-1 beta in Saccharomyces cerevisiae using a leader peptide from Candida albicans. Effect of N-linked glycosylation on biological activity. J Biol Chem. 1991;266(23):15348-55. https://doi.org/10.1 016/S0021-9258(18)98622-9.

57. Mangold CA, Wronowski B, Du M, Masser DR, Hadad N, Bixler GV, et al. Sexually divergent induction of microglial-associated neuroinflammation with hippocampal aging. J Neuroinflammation. 2017;14(1):141. https://doi. org/10.1186/s12974-017-0920-8

58. Katafuchi T, Takaki A, Take S, Kondo T, Yoshimura M. Endotoxin inhibitor blocks heat exposure-induced expression of brain cytokine mRNA in aged rats. Brain Res Mol Brain Res. 2003;118(1-2):24-32. https://doi.org/10.1016/ S0169-328X(03)00331-0.

59. Buchanan JB, Peloso E, Satinoff E. A warmer ambient temperature increases the passage of interleukin-1 beta into the brains of old rats. Am J Physiol Regul Integr Comp Physiol. 2008;295(1):R361-8. https://doi.org/10.1152/a jpregu.00104.2007.

60. Arisi GM. Nervous and immune systems signals and connections: cytokines in hippocampus physiology and pathology. Epilepsy Behav. 2014;38:43-7. https://doi.org/10.1016/j.yebeh.2014.01.017.

61. Tsakiri N, Kimber I, Rothwell NJ, Pinteaux E. Interleukin-1-induced interleukin- 6 synthesis is mediated by the neutral sphingomyelinase/Src kinase pathway in neurones. Br J Pharmacol. 2008;153(4):775-83. https://doi. org/10.1038/sj.bjp.0707610

62. Biber K, Neumann H, Inoue K, Boddeke HW. Neuronal 'On' and 'Off' signals control microglia. Trends Neurosci. 2007;30(11):596-602. https://doi.org/10.1 016/j.tins.2007.08.007.

63. Olsnes S, Klingenberg O, Wiedlocha A. Transport of exogenous growth factors and cytokines to the cytosol and to the nucleus. Physiol Rev. 2003; 83(1):163-82. https://doi.org/10.1152/physrev.00021.2002.

64. Jostock T, Mullberg J, Ozbek S, Atreya R, Blinn G, Voltz N, et al. Soluble gp130 is the natural inhibitor of soluble interleukin-6 receptor transsignaling responses. Eur J Biochem. 2001;268(1):160-7. https://doi.org/10.1046/ j.1432-1327.2001.01867.x

65. Narazaki M, Yasukawa K, Saito T, Ohsugi Y, Fukui H, Koishihara Y, et al. Soluble forms of the interleukin-6 signal-transducing receptor component gp130 in human serum possessing a potential to inhibit signals through membrane-anchored gp130. Blood. 1993:82(4):1120-6. https://doi.org/10.11 82/blood.V82.4.1120.1120.

66. Wei H, Chadman KK, McCloskey DP, Sheikh AM, Malik M, Brown WT, et al. Brain IL-6 elevation causes neuronal circuitry imbalances and mediates autism-like behaviors. Biochim Biophys Acta. 1822;2012(6):831-42. https:// doi.org/10.1016/j.bbadis.2012.01.011.

67. Balschun D, Wetzel W, Del Rey A, Pitossi F, Schneider H, Zuschratter W, et al. Interleukin-6: a cytokine to forget. FASEB J. 2004;18(14):1788-90. https://doi. org/10.1096/fj.04-1625fje.

68. Hueston CM, O'Leary JD, Hoban AE, Kozareva DA, Pawley LC, O'Leary OF, et al. Chronic interleukin-1 beta in the dorsal hippocampus impairs behavioural pattern separation. Brain Behav Immun. 2018;74:252-64. https:// doi.org/10.1016/j.bbi.2018.09.015.

69. Ni P, Dong H, Wang Y, Zhou Q, Xu M, Qian Y, et al. IL-17A contributes to perioperative neurocognitive disorders through blood-brain barrier disruption in aged mice. J Neuroinflammation. 2018;15(1):332. https://doi. org/10.1186/s12974-018-1374-3.

70. Rizzo FR, Musella A, De Vito F, Fresegna D, Bullitta S, Vanni V, et al. Tumor necrosis factor and interleukin-1beta modulate synaptic plasticity during neuroinflammation. Neural Plast. 2018;2018:8430123-12. https://doi.org/1 $0.1155 / 2018 / 8430123$.
71. Keegan AP, Paris D, Luis CA, Abdullah L, Ait-Ghezala G, Beaulieu-Abdelahad D, et al. Plasma cytokine IL-6 levels and subjective cognitive decline: preliminary findings. Int J Geriatr Psychiatry. 2018;33(2):358-63. https://doi. org/10.1002/gps.4752.

72. Singh-Manoux A, Dugravot A, Brunner E, Kumari M, Shipley M, Elbaz A, et al. Interleukin-6 and C-reactive protein as predictors of cognitive decline in late midlife. Neurology. 2014;83(6):486-93. https://doi.org/10.1212/WNL. 0000000000000665 .

73. Weaver JD, Huang MH, Albert M, Harris T, Rowe JW, Seeman TE. Interleukin6 and risk of cognitive decline: MacArthur studies of successful aging. Neurology. 2002;59(3):371-8. https://doi.org/10.1212/WNL.59.3.371.

74. Nenov MN, Malkov AE, Konakov MV, Levin SG. Interleukin-10 and transforming growth factor-beta1 facilitate long-term potentiation in CA1 region of hippocampus. Biochem Biophys Res Commun. 2019;518(3):48691. https://doi.org/10.1016/j.bbrc.2019.08.072.

75. Brombacher TM, Nono JK, De Gouveia KS, Makena N, Darby M, Womersley J, et al. IL-13-mediated regulation of learning and memory. J Immunol. 2017; 198(7):2681-8. https://doi.org/10.4049/jimmunol.1601546.

76. Mudo G, Frinchi M, Nuzzo D, Scaduto P, Plescia F, Massenti MF, et al. Antiinflammatory and cognitive effects of interferon-beta1a (IFNbeta1a) in a rat model of Alzheimer's disease. J Neuroinflammation. 2019;16(1):44. https:// doi.org/10.1186/s12974-019-1417-4.

77. Chen JH, Ke KF, Lu JH, Qiu YH, Peng YP. Protection of TGF-beta1 against neuroinflammation and neurodegeneration in Abeta1-42-induced Alzheimer's disease model rats. PLoS One. 2015;10(2):e0116549. https://doi. org/10.1371/journal.pone.0116549.

78. Sparkman NL, Buchanan JB, Heyen JR, Chen J, Beverly JL, Johnson RW. Interleukin-6 facilitates lipopolysaccharide-induced disruption in working memory and expression of other proinflammatory cytokines in hippocampal neuronal cell layers. J Neurosci. 2006;26(42):10709-16. https:// doi.org/10.1523/JNEUROSCI.3376-06.2006.

79. Godbout JP, Johnson RW. Interleukin-6 in the aging brain. J Neuroimmunol. 2004;147(1-2):141-4. https://doi.org/10.1016/j.jneuroim.2003.10.031.

80. McCarthy MM, Arnold AP, Ball GF, Blaustein JD, De Vries GJ. Sex differences in the brain: the not so inconvenient truth. J Neurosci. 2012;32(7):2241-7. https://doi.org/10.1523/JNEUROSCI.5372-11.2012.

81. Levine DA, Gross AL, Briceno EM, Tilton N, Giordani BJ, Sussman JB, et al. Sex differences in cognitive decline among US adults. JAMA Netw Open. 2021;4(2):e210169. https://doi.org/10.1001/jamanetworkopen.2021.0169.

82. Beam CR, Kaneshiro C, Jang JY, Reynolds CA, Pedersen NL, Gatz M. Differences between women and men in incidence rates of dementia and Alzheimer's disease. J Alzheimers Dis. 2018;64(4):1077-83. https://doi.org/1 0.3233/JAD-180141.

83. Shansky RM. Are hormones a "female problem" for animal research? Science. 2019;364(6443):825-6. https://doi.org/10.1126/science.aaw7570.

84. Steiner RA, Bremner WJ, Clifton DK, Dorsa DM. Reduced pulsatile luteinizing hormone and testosterone secretion with aging in the male rat. Biol Reprod. 1984;31(2):251-8. https://doi.org/10.1095/biolreprod31.2.251.

85. Machida T, Yonezawa Y, Noumura T. Age-associated changes in plasma testosterone levels in male mice and their relation to social dominance or subordinance. Horm Behav. 1981;15(3):238-45. https://doi.org/10.1016/0018506X(81)90013-1.

86. Frick KM. Estrogens and age-related memory decline in rodents: what have we learned and where do we go from here? Horm Behav. 2009;55(1):2-23. https://doi.org/10.1016/j.yhbeh.2008.08.015.

87. Mennenga SE, Bimonte-Nelson HA. Translational cognitive endocrinology: designing rodent experiments with the goal to ultimately enhance cognitive health in women. Brain Res. 2013;1514:50-62. https://doi.org/10.1 016/j.brainres.2013.01.020.

88. Yin F, Yao J, Sancheti H, Feng T, Melcangi RC, Morgan TE, et al. The perimenopausal aging transition in the female rat brain: decline in bioenergetic systems and synaptic plasticity. Neurobiol Aging. 2015;36(7): 2282-95. https://doi.org/10.1016/j.neurobiolaging.2015.03.013.

89. Surcel M, Constantin C, Caruntu C, Zurac S, Neagu M. Inflammatory cytokine pattern is sex-dependent in mouse cutaneous melanoma experimental model. J Immunol Res. 2017;2017:9212134-10. https://doi.org/10.1155/2017/ 9212134.

90. Bouchlaka MN, Sckisel GD, Chen M, Mirsoian A, Zamora AE, Maverakis E, et al. Aging predisposes to acute inflammatory induced pathology after tumor immunotherapy. J Exp Med. 2013;210(11):2223-37. https://doi.org/1 0.1084/jem.20131219. 
91. Secondary Progressive Efficacy Clinical Trial of Recombinant Interferon-Beta1a in MSSG: Randomized controlled trial of interferon- beta-1a in secondary progressive MS: clinical results. Neurology 2001, 56:1496-1504, 11, DOl: https://doi.org/10.1212/WNL.56.11.1496.

92. Nagashima T, Okubo-Fornbacher H, Aoki Y, Kamata Y, Kimura H, Kamimura $\mathrm{T}$, et al. Increase in plasma levels of adiponectin after administration of antitumor necrosis factor agents in patients with rheumatoid arthritis. J Rheumatol. 2008;35(5):936-8.

93. Ghanim H, Sia CL, Abuaysheh S, Korzeniewski K, Patnaik P, Marumganti A, et al. An antiinflammatory and reactive oxygen species suppressive effects of an extract of Polygonum cuspidatum containing resveratrol. J Clin Endocrinol Metab. 2010;95(9):E1-8. https://doi.org/10.1210/jc.2010-0482.

94. Witte AV, Kerti L, Margulies DS, Floel A. Effects of resveratrol on memory performance, hippocampal functional connectivity, and glucose metabolism in healthy older adults. J Neurosci. 2014;34(23):7862-70. https://doi.org/10.1 523/JNEUROSCI.0385-14.2014

95. Rancan L, Paredes SD, Garcia I, Munoz P, Garcia C, Lopez de Hontanar G, de la Fuente M, Vara E, Tresguerres JAF. Protective effect of xanthohumol against age-related brain damage. J Nutr Biochem 2017, 49:133-140, DOI: https://doi.org/10.1016/j.jnutbio.2017.07.011.

96. Campbell A, Sharman E, Bondy SC. Age-related differences in the response of the brain to dietary melatonin. Age (Dordr). 2014;36(1):49-55. https://doi. org/10.1007/s11357-013-9542-y.

97. Huang SY, Chen LH, Wang MF, Hsu CC, Chan CH, Li JX, et al. Lactobacillus paracasei PS23 delays progression of age-related cognitive decline in senescence accelerated mouse prone 8 (SAMP8) mice. Nutrients. 2018;10(7). https://doi.org/10.3390/nu10070894.

98. Paredes D, Acosta S, Gemma C, Bickford PC. Role of TNFalpha induced inflammation in delay eyeblink conditioning in young and aged rats. Aging Dis. 2010;1(3):191-8.

99. Dallagnol KMC, Remor AP, da Silva RA, Prediger RD, Latini A, Aguiar AS Jr. Running for REST: physical activity attenuates neuroinflammation in the hippocampus of aged mice. Brain Behav Immun. 2017;61:31-5. https://doi. org/10.1016/j.bbi.2016.07.159.

100. Gomes da Silva S, Simoes PS, Mortara RA, Scorza FA, Cavalheiro EA, da Graca Naffah-Mazzacoratti M, Arida RM: Exercise-induced hippocampal antiinflammatory response in aged rats. J Neuroinflammation 2013, 10:61, 1, DOl: https://doi.org/10.1186/1742-2094-10-61.

101. Speisman RB, Kumar A, Rani A, Foster TC, Ormerod BK. Daily exercise improves memory, stimulates hippocampal neurogenesis and modulates immune and neuroimmune cytokines in aging rats. Brain Behav Immun. 2013;28:25-43. https://doi.org/10.1016/j.bbi.2012.09.013.

102. Ng TKS, Fam J, Feng L, Cheah IK, Tan CT, Nur F, et al. Mindfulness improves inflammatory biomarker levels in older adults with mild cognitive impairment: a randomized controlled trial. Transl Psychiatry. 2020;10(1):21. https://doi.org/10.1038/s41398-020-0696-y.

103. Shields GS, Spahr CM, Slavich GM. Psychosocial interventions and immune system function: a systematic review and meta-analysis of randomized clinical trials. JAMA Psychiatry. 2020;77(10):1031-43. https://doi.org/10.1001/ jamapsychiatry.2020.0431.

104. Bordner KA, Kitchen RR, Carlyle B, George ED, Mahajan MC, Mane SM, et al. Parallel declines in cognition, motivation, and locomotion in aging mice: association with immune gene upregulation in the medial prefrontal cortex. Exp Gerontol. 2011;46(8):643-59. https://doi.org/10.1016/j.exger.2011.03.003.

\section{Publisher's Note}

Springer Nature remains neutral with regard to jurisdictional claims in published maps and institutional affiliations.

Ready to submit your research? Choose BMC and benefit from:
- fast, convenient online submission
- thorough peer review by experienced researchers in your field
- rapid publication on acceptance
- support for research data, including large and complex data types
- gold Open Access which fosters wider collaboration and increased citations
- maximum visibility for your research: over 100M website views per year
At BMC, research is always in progress.
Learn more biomedcentral.com/submissions

